\title{
Groundwater management of a highly dynamic karst by assessing baseflow and quickflow with a rainfall-discharge model (Dardennes springs, SE France)
}

\author{
Cécile Baudement ${ }^{1, *}$, Bruno Arfib ${ }^{1}$, Naomi Mazzilli ${ }^{2}$, Johan Jouves ${ }^{1}$, Thierry Lamarque ${ }^{3}$ \\ and Yves Guglielmi ${ }^{1,4}$ \\ 1 Aix-Marseille Univ, CNRS, IRD, Coll France, CEREGE, Aix-en-Provence, France \\ 2 Université d'Avignon et des Pays de Vaucluse - INRA, UMR1114 EMMAH, Avignon, France \\ 3 Association Spélé-H2O, av. Bucarin, Six-Fours, France \\ ${ }^{4}$ Lawrence Berkeley National Laboratory, Berkeley, United States
}

\begin{abstract}
This paper aims at characterizing the groundwater flow in a highly dynamic karst aquifer using a global modeling approach based on rainfall and spring discharge time series. The Dardennes aquifer (SE France) was studied as it is used for drinking water supply and it also produces karst flash floods that increase the flood hazard downstream in urban areas. Three years of data were available, including a normal rainy year, a wet year and a dry year. Modeling was performed with the new platform KarstMod, a rainfalldischarge model with calibration tools. The Dardennes aquifer model was structured with three interconnected reservoirs: Epikarst, Matrix, and Conduit. Using this modeling approach, we were able to determine the groundwater hydrograph separation of the karst spring discharge, at the annual scale and at the event scale (flood). This gives insight into the low flow (Matrix) available for the drinking water demand and the fast flow (Conduit) that generates flash floods. In such a dynamic aquifer, part of the water budget cannot be accounted for by water resources as fast flow is not stored within the aquifer and is not available for the drinking water demand. The results were compared with the current groundwater management to determine whether the withdrawal is sustainable. Depending on whether it is a wet or a dry year, the proportion of slow flow ranges from 27 to $61 \%$ of the total discharge, respectively. During floods in high water periods, the proportion of quickflow increases drastically up to more than $90 \%$ of the spring discharge. In the case of a $300 \mathrm{~mm} / \mathrm{d}$ simulated Mediterranean rainfall event, the mean daily peak value may reach $74 \mathrm{~m}^{3} / \mathrm{s}$. This discharge can be reduced if the aquifer is previously depleted, which increases the storage within the aquifer. Coupling the geological context and the model results opens up future perspectives for the active management of the karst aquifer.
\end{abstract}

Keywords: Karst / rainfall-discharge model / lumped model / hydrograph separation / recession coefficient / water management / flash flood

\begin{abstract}
Résumé - Gestion des eaux souterraines d'un karst hyper dynamique par l'évaluation du débit de base et du débit rapide avec un modèle Pluie-Débit (sources de Dardennes, SE France). Cet article a pour but de caractériser l'écoulement d'eau souterraine à travers un aquifère karstique fortement dynamique en utilisant une approche de modélisation globale basée sur les séries temporelles des précipitations et des débits. L'aquifère de Dardennes (SE de la France) est pris comme cas d'étude car il est d'une part utilisé pour l'alimentation en eau potable et d'autre part il génère des crues éclair karstiques qui augmentent le risque inondation en aval, en zone urbaine. Trois années de données sont disponibles, incluant une année pluvieuse normale, une année très pluvieuse et une année sèche. La modélisation est réalisée avec la nouvelle plateforme KarstMod, un modèle à réservoirs pluie-débit avec des outils de calage automatique. Le modèle de l'aquifère de Dardennes est structuré avec trois réservoirs interconnectés : Epikarst, Matrice et Conduit. Grâce à cette approche de modélisation, nous avons effectué une déconvolution du débit des sources, à l'échelle annuelle et à l'échelle des événements de crue. Cela permet de séparer le débit de base (Matrice)
\end{abstract}

*Corresponding author: cecile.baudement@gmail.com 
disponible pour les besoins en eau potable et l'écoulement rapide (Conduit) qui génère des crues éclairs. Dans les systèmes hyper-dynamiques, une partie de l'eau qui transite ne peut pas être comptabilisée comme ressource en eau car l'écoulement rapide n'est pas stocké dans l'aquifère et n'est donc pas disponible pour alimenter la demande en eau potable. Les résultats sont comparés avec la gestion actuelle des eaux souterraines afin de montrer si l'exploitation de l'eau est durable. Selon l'année, la proportion de débit de base varie entre 27 et $61 \%$ du débit total, respectivement selon une année pluvieuse ou sèche. Lors des crues en période de hautes-eaux, la proportion du débit rapide augmente considérablement jusqu'à plus de $90 \% \mathrm{du}$ débit total des sources. Dans le cas d'un événement pluvieux de type Méditerranéen avec $300 \mathrm{~mm} / \mathrm{j}$ de pluie, le débit moyen maximum simulé avec le modèle atteint $74 \mathrm{~m}^{3} / \mathrm{s}$. Ce débit peut être réduit si l'aquifère est déjà déprimé, ce qui augmente le stockage de l'eau. Le couplage du contexte géologique et des résultats du modèle ouvre une perspective future pour une gestion active de cet aquifère karstique.

Mots clés : Karst / modèle pluie- débit / modèle global / déconvolution d'hydrogramme / coefficient de récession / gestion de l'eau / crue éclair

\section{Introduction}

Highly dynamic karst aquifers are characterized by rapid and high changes in spring flow rate, producing high floods, in response to rainfall events. This dynamic behavior can be achieved by specific in situ geological, speleogenetic (Audra and Palmer, 2013) and hydraulic features that enable a rapid pressure wave propagation from the infiltration zone to the discharge zone of the aquifer (main and overflow springs). Moreover, Geyer et al. (2008) and Covington et al. (2009) showed that the spring discharge is highly correlated to the recharge intensity in a conduit-dominated flow karst system. The high dynamics of karst systems have a great impact on flood hazard and drinking groundwater management. First, flash floods in streams are correlated to run-off on urban (Miller et al., 2014) or impervious geological surfaces, and increase in the Mediterranean environment due to the extreme Mediterranean rain-type (Merz and Bloschl, 2003; Nied et al., 2014) and karst contribution (Maréchal et al., 2008; Vannier et al., 2016). Second, the volume of groundwater discharged during floods represents a high recharge rate. As a result, this volume is not available for the drinking water supply. The water balance needed to estimate a sustainable yield should account for the proportion of groundwater that does not constitute an available reserve. However, when the highly transmissive karst network is located below the base level, it constitutes a natural storage zone, which reconstitutes rapidly during floods and connects and drains the low permeable matrix blocks (Kovács and Perrochet, 2008). Moreover, Jourde et al. (2013) showed the mitigation effect of a depleted karst network on floods. Pumping in such a karst network during a low flow period depletes the water level below the spring base level, which in turn allows storage of the first rainfall events in this man-induced epiphreatic zone below the overflow level. This kind of groundwater management, called active management, mitigates the flood discharge at the outlet of the aquifer (usually the spring), and proportionally increases the groundwater storage for future use as drinking water.

In this paper, we studied the Dardennes karst system, located in the South-East of France. This area is highly tectonized, in the main thrust zone of Provence. The groundwater recharge zone is close to $70 \mathrm{~km}^{2}$. The aquifer develops a thick vadose zone (up to $500 \mathrm{~m}$ in average) and a thick saturated zone below the springs' outflow level (more than $500 \mathrm{~m}$ ). Groundwater flows out in several permanent springs and one overflow-type spring (Lamarque et al., 2008). Three years of daily discharge are available ranging from $100 \mathrm{~L} / \mathrm{s}$ to more than $27 \mathrm{~m}^{3} / \mathrm{s}$. The climate is Mediterranean. The groundwater is used for the drinking water supply of Toulon city. The remaining water discharges to the Las stream, which flows to the Mediterranean sea through Toulon with flash floods from urban runoff and karst floods. Toulon faces two problems:

- in low flow periods, the natural discharge of the Dardennes springs is not sufficient for the drinking water demand and water quality is deteriorated by surface storage in a dam; - during high rainfall Mediterranean events, karstic floods increase the risk of flood hazard within the urban area.

Predicting the spring flow rate with such rapid and extreme increases is thus a key challenge, which is hard to achieve given the dual behavior of flow within karst aquifers, schematically characterized by very fast and very slow groundwater flows. Numerous modeling studies have been published in recent decades to characterize the hydrodynamics of karst aquifers (e.g., Goldscheider and Drew, 2007). Global models include spring hydrograph analytical methods to provide information on the behavior or functioning of the entire karst system. Rainfall-discharge analyses have been applied at two different scales: to single storm events; to the entire time series in response to a succession of rainfall events. Recession analysis provides groundwater separation in several flow components, by fitting the basic Maillet law or adapted analytical formulae (Atkinson, 1977; Fiorillo, 2014; Kovács and Perrochet, 2008; Mangin, 1975; White, 2007). The application of recession analysis gives insight into the groundwater flows within the aquifer. For instance Padilla et al. (1994) and Fu et al. (2016) quantified the quickflow and baseflow of karst springs. Discharge variation versus chemical, electric conductivity, temperature or turbidity variation is also a classical tool to investigate aquifer behavior at the flood scale, using graphical analysis of chemographs or a hysteresis loop in XY plots (Bakalowicz, 1979; Chanat et al., 2002; Perrin et al., 2007; Valdes et al., 2006). Time series analyses have been successfully applied to karst aquifers to investigate the rainfall-discharge relationship at the global scale (e.g., Delbart et al., 2016; Denic-Jukic and Jukic, 2003; Mathevet et al., 2004; Padilla and Pulido-Bosch, 1995). 
Another complementary type of commonly used modeling approach is to build a lumped or conceptual rainfalldischarge model with linear discharge (Bezès, 1976; Fleury, 2005; Mero, 1964; Padilla-Benitez, 1990). Lumped models distribute water infiltration into several "reservoirs" that isolate the key flow components of a given karst system. The number and properties of the reservoirs can be adjusted to match each case study, but contain some common features (Hartmann et al., 2012) such as: i) the recharge is computed in the first shallow reservoir usually called Soil or Epikarst. The simplest structure supplies the spring directly, or supplies one lower reservoir between the Epikarst and the spring; ii) the most common structure uses two lower reservoirs in order to simulate a slow component (slow or matrix reservoir), and a quickflow (fast or conduit reservoir). The two lower reservoirs can be in parallel and separated (Bezès, 1976), or in parallel with water exchange between them (Rimmer and Hartmann, 2012), or in parallel but water from the matrix has to pass the conduit system before it reaches the spring (Geyer et al., 2007). Other structures also exist: Hartmann et al. (2012) tested two lower reservoirs in series, while Arfib and Charlier (2016) added a third reservoir. These models were used to discuss the regional karst groundwater resources (Bakalowicz, 2005; Fleury et al., 2009; Ladouche et al., 2014), as a tool for the identification and quantification of flow (Fleury et al., 2007), to assess the vulnerability (Butscher and Huggenberger, 2008), to estimate the groundwater balance (Jukić and Denić-Jukić, 2009), or for flood hazard (Fleury et al., 2013). The main advantage of lumped models is that they can run even if the observed discharge time series is not complete, which is one of the main limitations of time series analysis. Furthermore, the separation of groundwater flow components can be achieved at various scales: at the annual scale, to investigate the recharge of the matrix of the aquifer, or at the event scale to investigate the rapid transfer from rainfall to flood.

This paper aims at characterizing a highly dynamic karst aquifer using a global approach with a lumped reservoir rainfall-discharge model. The new platform KarstMod (Mazzilli et al., 2017) was used to improve knowledge about the hydrodynamic behavior of the Dardennes case study. With this modeling approach, we were able to achieve the groundwater hydrograph separation of the karst spring discharge, to quantify the low flow (Matrix) available for the drinking water demand and the fast flow (Conduit) that generates flash floods and is not stored within the aquifer (and so is not available for the drinking water demand). Modeling results were interpreted in the light of geological and speleogenetic knowledge. The model was then used to predict flood discharge in the case of a Mediterranean rain event up to $300 \mathrm{~mm} /$ day, as observed in a nearby recent example, "Draguignan" event (Meteo-France, 2017b; Ruin et al., 2014). The groundwater management is then discussed in the light of the geological and modeling results.

The paper is structured in three main sections. First, the geological and hydrogeological settings of the Dardennes system are presented. Second, the conceptual structure of the model and the modeling strategy are explained, based on the KarstMod tool. Third, results are discussed in order to show the specific behavior of the dynamic karst of Dardennes and the consequences for groundwater management.

\section{Case study: Dardennes karst system}

\subsection{Geological setting}

In the Mediterranean area, karst aquifers are important groundwater reserves nested in carbonate series that experienced complex geodynamic and climatic histories. The Dardennes springs are located in south-eastern France, close to the city of Toulon (Fig. 1a). Toulon is located in Provence, on the boundary between the crystalline (Permian) and the carbonate Provence. Some major E-W trending thrust faults were identified in the basement (Bestani et al., 2015), affecting the Triassic (Roure et al., 1992) and then evolving into major detachment zones in the Mesozoic carbonate succession along a shallow décollement level located in the Callovo-Oxfordian marls (Roure and Colletta, 1996). This present-day structure of the studied area results from polyphase tectonic events and is characterized by two main fault families, $\mathrm{N} 020-060^{\circ}$ and $\mathrm{N} 110-140^{\circ}$ in addition to the main thrust systems. From early Cretaceous to late Cretaceous, the regional uplift called the "Durance uplift" brought to the surface the upper Jurassic to lower Cretaceous carbonates (Guyonnet-Benaize et al., 2010; Masse and Philip, 1976). This event is associated to a stratigraphic hiatus and unconformities with patches of bauxite deposits (Laville, 1981). Southeastern Provence was then affected by one main compression phase: a N-S PyreneanProvence compression during the late Cretaceous to Eocene (Lacombe and Jolivet, 2005). The Toulon sedimentary unit is a 2-3 km- thick pile of Silurian-to-Cenozoic rocks (Fig. 1b), including evaporates, limestones, dolomites, marls and sandstones.

Speleogenesis has been influenced by several tectonic phases and sea level variations. During the Aptian-Albian, the Durancian uplift favored the development of a regional erosion surface with bauxite deposits, sometimes trapped in the karst networks (Laville, 1981). During the Cenomanian, several emersions occurred associated to the formation of karst surfaces (Hennuy, 2003; Matonti, 2015). At the end of the Cretaceous, Pyrenean- Provence orogeny induced an erosion and an intense deformation of the karst system resulting in an entire sealing of the cavities (Blanc, 1997). During the Oligocene, a major rifting phase occurred and extended the opening process of the Mediterranean by creating leveling surfaces (Blanc, 1992). Variations in the Mediterranean Sea level impacted the carbonate karstification. Several authors (Audra et al., 2004; Mocochain et al., 2009) have shown that the Messinian salinity crisis (1-to- $2 \mathrm{~km}$ decrease in the Mediterranean sea level) induced first a deepening of the karst drainage system and then a flooding after the Pliocene transgression. The drowning of the Messinian conduits led to the reorganization of the drains after a rise in the base level. This reorganization generated deep phreatic karst systems connected to vauclusian springs by chimney-shafts, with perascensum speleogenesis (Mocochain et al., 2011). In the saturated zone of the aquifer, these chimney-shafts may act as connecting or draining channels between the deep part of the aquifer and the current base level, as was shown in the submarine spring of Port-Miou (Arfib and Charlier, 2016) located $34 \mathrm{~km}$ westward of the Dardennes case-study.

The Dardennes karst extends over the Siou Blanc massif, a $110 \mathrm{~km}^{2}$ karst plateau located northwards from Toulon (Fig. 1). 
(a) Structural map

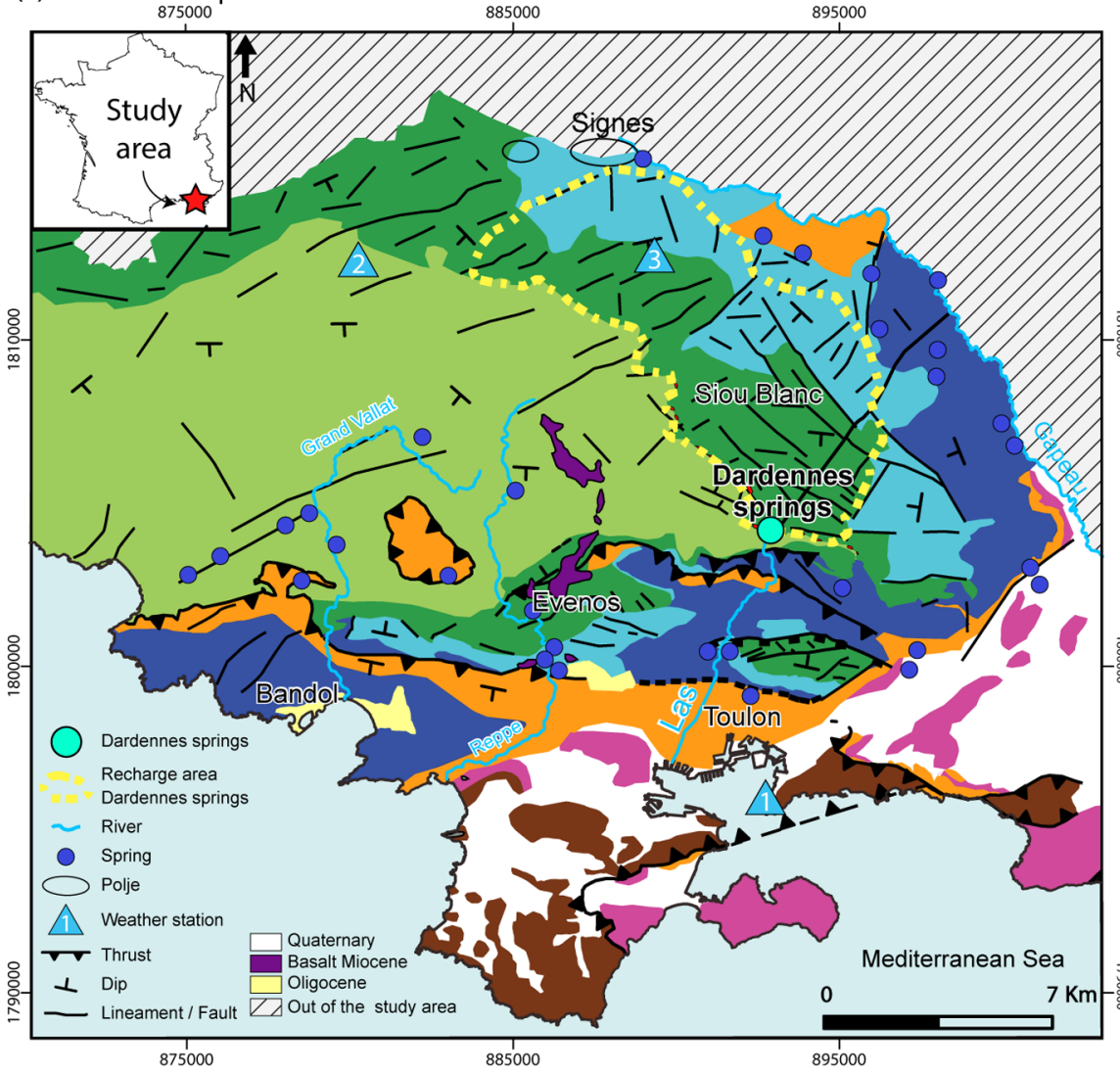

(b) Synthetic stratigraphic column

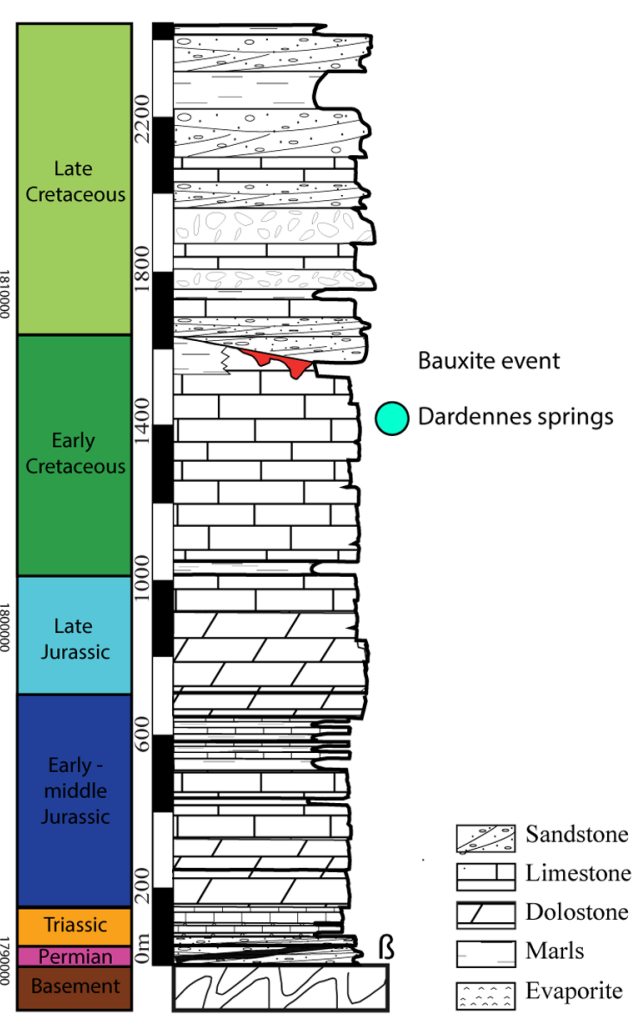

Fig. 1. (a) Structural map of the Toulon area (SE. France). Hydrogeological items are also added to the map: springs, rivers, rain gauges, limit of the recharge area of the Dardennes springs (b) Synthetic stratigraphic column of the study area.

The mean altitude is 650 m.a.s.1, with the highest point at 826 m.a.s.l. In the central area of this plateau, the $300 \mathrm{~m}$ thick Barremian limestones with Urgonian facies are exposed. The eastern Siou Blanc plateau consists of 400-meter-thick late Jurassic dolomites. The western plateau consists of $300 \mathrm{~m}$ thick rudist-rich Turonian limestones. This plateau shows intense karstification and epikarst development. About 1000 caves were identified with 32 deep caves exceeding 100 meters in depth (Lamarque et al., 2008; Lucot and Chardin, 2017). Most of the caves are vertical shafts. Some of them have been explored by cavers to more than $300 \mathrm{~m}$ deep and they never observed the water table. Over the plateau, karst features are present at various scales, including sinkholes, dolines, polje, karren and many caves that favor concentration of water infiltration. No surface streams are identified; all the rainfall infiltrates.

\subsection{Hydrogeological setting and current water management}

The Dardennes aquifer has several perennial spring outlets (Fig. 2). These springs outflow in an artificial lake at an elevation around $100 \mathrm{~m}$.a.s.l. The maximum discharge recorded during the studied period (2012-2016) was $27 \mathrm{~m}^{3} /$ $\mathrm{s}$, but it probably reached more than $50 \mathrm{~m}^{3} / \mathrm{s}$ during previous historical floods (Lamarque et al., 2008). During low flow
North

South

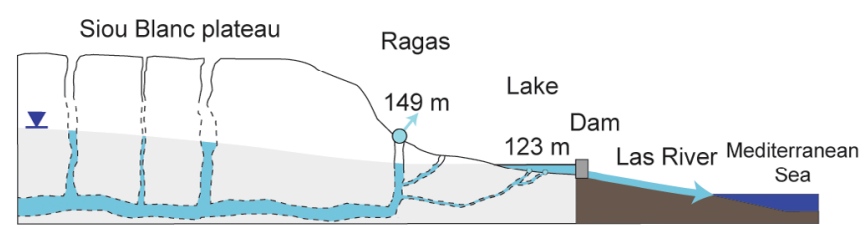

Not to scale

Fig. 2. Conceptual cross-section of the Dardennes aquifer.

periods, the flow rate is less than $100 \mathrm{~L} / \mathrm{s}$. The Dardennes springs have been used as a fresh-water supply for the city of Toulon for more than a century. A dam was built in 1913 downstream the springs to create a reserve available during the low flow period. The springs then outflow into the artificial lake. The lake level, which is controlled and monitored by the water-supply company, fluctuates from 123 m.a.s.l in winter to 110 to 115 m.a.s.1 in summer. Above $123 \mathrm{~m}$ the lake water overflows by a spillway to the downstream Las river. This is an $8 \mathrm{~km}$ long river that flows through Toulon to the Mediterranean Sea. The average amounts of water supplied to Toulon from the karst withdrawal in 2013, 2014 and 2015 were respectively $18433 \mathrm{~m}^{3} / \mathrm{d}, 16504 \mathrm{~m}^{3} / \mathrm{d}$ and $13249 \mathrm{~m}^{3} / \mathrm{d}$. When the discharge from natural springs is lower than the water needs, in low flow periods, water is withdrawn from the artificial lake, thus decreasing its water level. 
a) $18^{\text {th }}$ January 1999

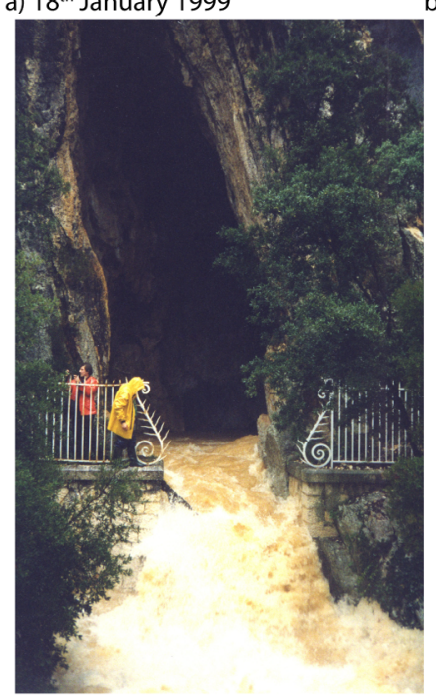

b) $8^{\text {th }}$ October 2013

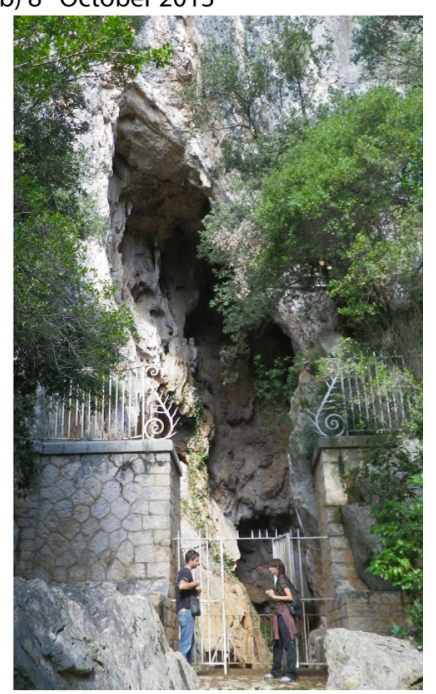

Fig. 3. The Ragas cave (b) or overflow spring (a). Photo taken on 18th January 1999: one of the highest karst floods observed over the last three decades at the Ragas. The rainfall recorded at the Toulon station and Le Castellet aerodrome station was respectively $90 \mathrm{~mm} / \mathrm{d}$ and $110 \mathrm{~mm} / \mathrm{d}$ on 17th January 1999 (with a previous rainfall event on 10th January 1999 of $66 \mathrm{~mm}$ in Toulon and $56 \mathrm{~mm}$ in Castellet); no data were available on the Siou-Blanc plateau where the rainfall is usually higher.

Five hundred meters upstream from the main perennial springs and the lake, there is an overflow karst Vauclusian-type spring called the "Ragas", with an overflow threshold at $149 \mathrm{~m}$. a.s.1 (Fig. 3). Its level is controlled by the lake water level except during flood peaks, when the hydraulic head increases in the karst network and overflows up to 149 m.a.s.l. The Ragas spring gives access to a main $150 \mathrm{~m}$ deep vertical karst conduit explored by cave-divers (Lamarque et al., 2008), which is a typical karst chimney-shaft (Mocochain et al., 2011). All these springs are called the "Dardennes springs". According to geological studies, their recharge area was estimated between 50 and $70 \mathrm{~km}^{2}$. The aquifer is mainly composed of tight limestones of the early Cretaceous and dolomites of the late Jurassic (Fig. 1).

The climate is Mediterranean, with a mean annual precipitation usually below $1000 \mathrm{~mm} / \mathrm{y}$ that mostly falls from November to March. One main feature of the region is the occurrence of very intense rainfall events (Gaume et al., 2009), called Mediterranean events, with daily rainfall higher than $100 \mathrm{~mm} / \mathrm{d}$ and exceptional intensity up to $300 \mathrm{~mm} / \mathrm{d}$ (MeteoFrance, 2017a).

\subsection{Data}

Available data are rainfall and evapotranspiration in the recharge area of the Dardennes springs, and water level and flow rate in the main springs. The study period lasted from 10/ $15 / 2012$ to $01 / 26 / 2016$. Daily precipitations were recorded at three weather stations (see location in Fig. 1): \#1, Toulon (elevation $23 \mathrm{~m}$, at the seaside), \#2, Le Castellet (elevation $417 \mathrm{~m}$, on a topographic plateau between the sea and the mountain), and \#3, Limate (elevation $690 \mathrm{~m}$, on the Siou Blanc plateau). The average annual rainfall is $850 \mathrm{~mm}$ and the number of rainy days is about 100 per year. Potential evapotranspiration (ET) is only available at the Le Castellet station, located in a representative mean position of the recharge area. ET is less variable than precipitation and can be roughly approximate.

Water levels were recorded by pressure sensors at a 15 -minute time-step in the Ragas karst conduit (Fig. 2). The Dardennes springs' discharge is the sum of the discharge to the Las river downstream from the dam, the withdrawal water discharge for water supply, the lake evaporation and the management balance of the lake water volume by the dam factory. This discharge was computed at a daily time-step, i.e., the time-step of the lake and water supply data available. The mean daily rainfall was computed by taking the mean value of the three available raingauges, which integrates the spatiotemporal variations in rainfall over the recharge area.

\subsection{Main springs' hydrodynamic response}

Figure 4 shows three and half years of daily discharge, lake water level, evapotranspiration and rainfall time series, and the 15-minute time-step Ragas water level. The spring hydrograph shows two trends:

- seasonal variations with a high water period between November and April and a low flow period between May and October;

- flood peaks corresponding to rain events.

The mean discharge was about $1.1 \mathrm{~m}^{3} / \mathrm{s}$ during the studied period. The Dardennes springs are characterized by a low but non-zero baseflow value, and a typical karst-type response with high-flood events of short duration. The maximum daily rainfall value observed over the whole period studied was $80 \mathrm{~mm} / \mathrm{d}$. There were 92 rainfall events higher than $10 \mathrm{~mm} / \mathrm{d}$ over the studied period (1199 days). Most of them had a low intensity below $20 \mathrm{~mm} / \mathrm{d}$, 39 events were between 20 and $40 \mathrm{~mm} / \mathrm{d}$ and 10 higher than $40 \mathrm{~mm} / \mathrm{d}$ with one higher than $80 \mathrm{~mm} / \mathrm{d}$. As the modeling results will be presented by calendar year in the following sections in order to have complete years of data, the rainfall time-series was divided up by calendar year, but it was checked that the cumulative annual height of water was close to the hydrologic division. The three complete years studied showed different behaviors: 2013 was a normal year with $948 \mathrm{~mm}$ of rainfall, 2014 was a wet year with $1180 \mathrm{~mm}$ of rainfall and 2015 was dry, with only $578 \mathrm{~mm}$ of rainfall.

The water level in the lake and in the Ragas conduit is almost the same, except during flood events (Fig. 4). The lake water level remains close to 123 m.a.s.l when the lake overflows during the winter period, i.e., when discharge from the springs is higher than the lake evaporation and withdrawal for the water supply. At the end of the spring season until autumn, the lake water level decreases depending on the discharge from the springs, evaporation and withdrawal. Between November 2012 and May 2013, the lake water level was essentially controlled by the release of lake water to the downstream river. At the daily time-step that was used for discharge modeling, the time lag observed between a rain event 

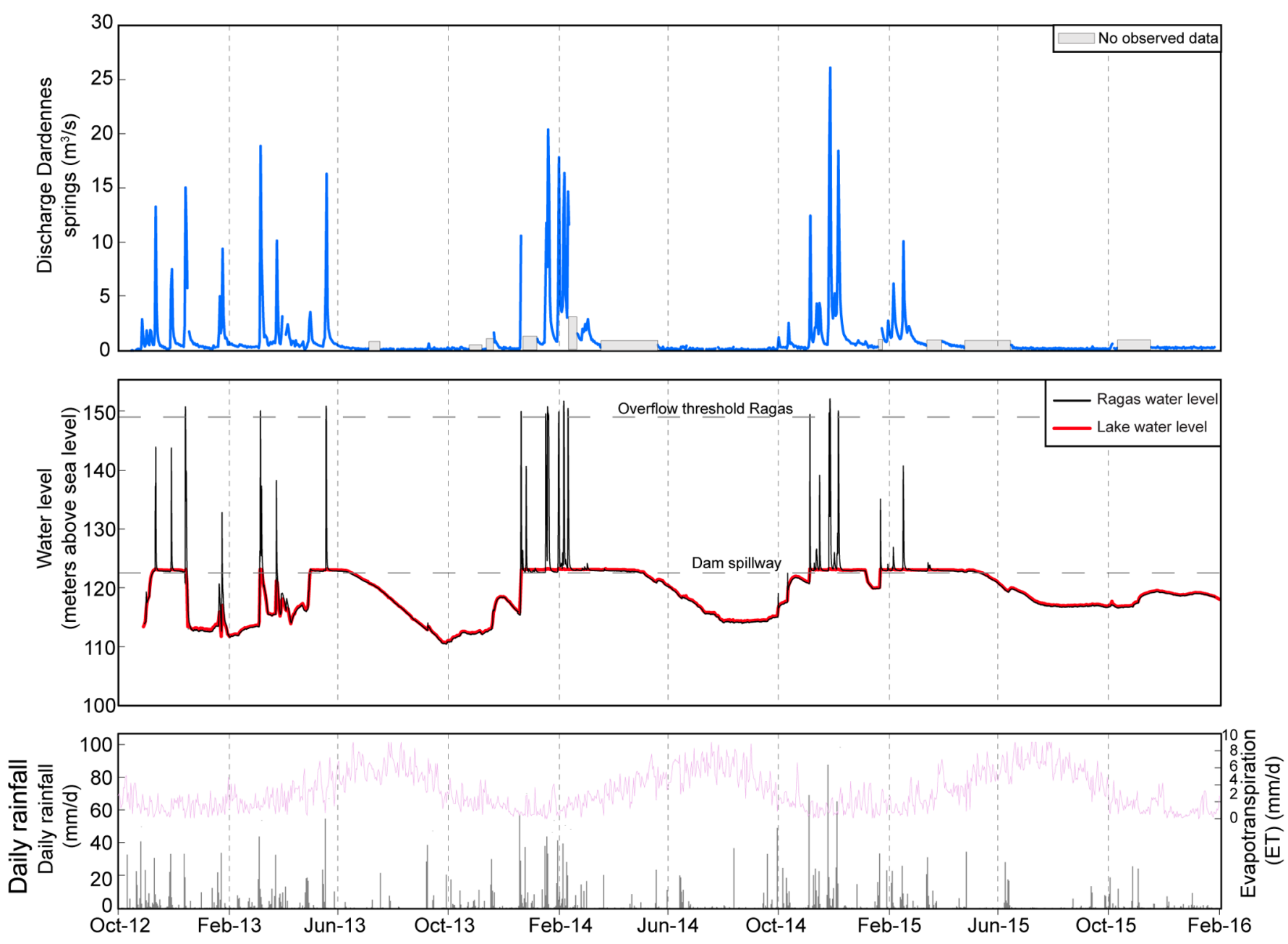

Fig. 4. Discharge $\left(\mathrm{m}^{3} / \mathrm{s}\right)$, water level $(\mathrm{m})$, evapotranspiration and rainfall $(\mathrm{mm} / \mathrm{d})$ time series of the Dardennes karst hydrosystem. Daily rainfall is computed using rain gauge data from the Toulon, Le Castellet and Limate stations. Water level is plotted at a 15-minute time-step and discharge is computed at a daily time-step.

and the water level or discharge variation at the springs is only one day. However, the intensity of the response of the springs (observed at the lake or the Ragas) to a rainfall event is linked to the time the event occurs in the hydrologic cycle. During low flow periods (summer and autumn), the discharge variation is very low (Fig. 4). The rainfall infiltrated is then stored in the soil, in the epikarst and in the thick vadose zone (up to 500 meters). During high water periods, rain events succeed each other, the springs' discharge is higher than the water supply withdrawal, the lake water level increases and the Ragas overflows. The Ragas spring overflowed 14 times during the study period. The Ragas karst conduit is connected to the karst network and acts as a natural piezometer.

As shown in Figure 4, the Dardennes aquifer is a highly dynamic karst aquifer, with a quick spring response to the rain, and high discharge variations that generate flash floods. The discharge varies very quickly after a rain event in the high flow period whatever the initial level in the lake. For instance, the lake water level was low in February and March 2013 (Fig. 4) when a rain event of $61 \mathrm{~mm} / \mathrm{d}$ occurred on 5th and 6th March 2013; in one day, the observed discharge increased from
$0.8 \mathrm{~m}^{3} / \mathrm{s}$ to $18.8 \mathrm{~m}^{3} / \mathrm{s}$, returning to its initial value about ten days later. During this flood, the Ragas overflowed and its water level reached $150.1 \mathrm{~m}$.a.s.l, i.e., $1.1 \mathrm{~m}$ above the karst threshold. Another example of the dynamism of this karst aquifer can be observed during the five floods following each other between 16th January and 10th February 2014. During this 25-day period, the lake was at its maximum level $(123 \mathrm{~m})$; five daily rainfall events ranging between 30 and $44 \mathrm{~mm} / \mathrm{d}$ generated five Ragas overflow and five karst floods ranging between 12 and $20 \mathrm{~m}^{3} / \mathrm{s}$ (daily mean). The maximum velocity of the water level increase in the Ragas conduit during the rising limb was close to 5 to $7 \mathrm{~m} / \mathrm{h}$ (observed with data at a 15 minute time-step - figure not shown here), leading to an overflow in a few hours, and around $2 \mathrm{~m} / \mathrm{h}$ during the falling limb.

To summarize, the Dardennes aquifer is characterized by two main flow components:

- a baseflow with smooth variations over the year, which during the low flow period supplies the springs exclusively;

- a very dynamic flow during rainfall events, which generates floods and a high water level in the karst network connected to the Ragas overflow spring. 


\section{Methods: rainfall-discharge modeling}

\subsection{Governing equation and model structure}

In order to model the rainfall-discharge relationship of the Dardennes springs, the KarstMod platform (version 2.19) was used at a daily time-step (Mazzilli et al., 2017). It provides an adjustable modeling platform for discharge simulations and for hydrodynamic analysis. KarstMod can reproduce the conceptual structure of the global karst models known in the literature (Bezès, 1976; Fleury, 2005; Fleury et al., 2007; Mero, 1964). The model is composed of connected reservoirs that fill and empty, converting rainfall amounts into discharge at the outlet of the system.

On the KarstMod platform, several model structures can be chosen: an upper reservoir (representing the soil and epikarst of the karst system) that cannot be deactivated and one, two or three lower reservoirs. The model structure was built according to the functioning of the Dardennes aquifer previously described. The Matrix reservoir (equivalent to the geological matrix and small fissures and fractures in the saturated and vadose zone) is first added as a lower reservoir to represent the baseflow. As the second component of the flow is very dynamic in the Dardennes aquifer, there are two solutions to accurately represent the fast flow in the lumped model: 1) a direct flow that connects the Epikarst reservoir to the spring, or, 2) a fast flow between the Epikarst reservoir to a lower reservoir, the Conduit reservoir, and then to the spring. The Conduit reservoir represents the highly permeable karst conduits. This second solution has the great advantage of producing water level simulation in the Conduit reservoir for the fast flow (or conduit) component of the aquifer. We chose this model structure in order to subsequently compare the simulated level in the Conduit reservoir to the observed Ragas conduit water level of the case study.

Therefore, we structured the lumped model with three reservoirs (Fig. 5): Epikarst (E), Matrix (M) and Conduit (C). The Epikarst reservoir is a shallow interface between the topographic surface of the recharge area and the other reservoirs. Recharge to the $\mathrm{M}$ and $\mathrm{C}$ reservoirs is available only when the water level is positive in reservoir $\mathrm{E}$. This reservoir is characterized by a minimum water level $\mathrm{E}_{\min }$ (negative value) that represents the available quantity of water stored in the soil for evapotranspiration that will not recharge the aquifer. This is a key parameter to avoid groundwater recharge and spring floods for small rainfall during dry periods. The $\mathrm{E}_{\text {ThresholdC }}$ (Fig. 5) represents a threshold water level that has to be exceeded in order to allow a fast flow to the Conduit reservoir. This parameter is useful to generate high floods above a recharge threshold during high rainfall events. Since our goal was to separate the hydrograph between baseflow (reservoir $\mathrm{M}$ ) and fastflow (reservoir C), we did not add an exchange flow between $\mathrm{M}$ and $\mathrm{C}$. However, we tested another model structure with the M-C exchange and verified that the model performance was neither better nor worse. Obviously, this modeling constraint highlights that the reservoir model should be viewed here as a tool to estimate the flow components in a lumped procedure, and does not represent the accurate spatial distribution of karst and matrix within the aquifer. The total simulated discharge of the spring is the sum of the slow and fast components, but it gives no insight into the role of the karst

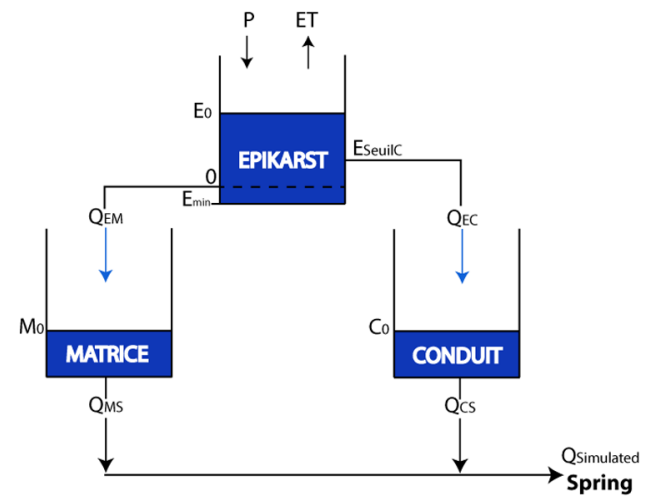

Fig. 5. Structure of the rainfall-discharge reservoir model. ET the potential evapotranspiration. E0, M0, C0 the initial water level in the Epikarst, Matrix and Conduit reservoirs respectively. Emin the minimum water level in the Epikarst reservoir. EThresholdC a threshold level for discharge to the conduit reservoir. QEM and QEC the discharge from the Epikarst reservoir to the Matrix and Conduit reservoirs. QMS and QCS the discharge from the Matrix and Conduit reservoirs to the Spring.

network connected to the spring as a draining or supplying structure of the matrix.

Each reservoir is defined by its recession coefficient $k$ that has to be calibrated. The model is calibrated by selecting the optimal parameters set to best match the simulated outlet discharge to the observed one. The mass balance equations are the following:

$$
\begin{gathered}
\frac{d E}{d t}=P-E T-Q_{E M}-Q_{E C} \\
\frac{d M}{d t}=Q_{E M}-Q_{M S} \\
\frac{d C}{d t}=Q_{E C}-Q_{C S}
\end{gathered}
$$

where $Q_{E M}=k_{E M} \times E_{t}$ if $E_{t}>0$, otherwise $Q_{E M}=0$

$$
Q_{E C}=k_{E C} \times\left(E_{t}-E_{\text {ThresholdC }}\right)
$$$$
\text { if } E_{t}>E_{\text {ThresholdC, }} \text { otherwise } Q_{E C}=0
$$

$$
\begin{gathered}
Q_{M S}=k_{M S} \times M_{t} \\
Q_{C S}=k_{C S} \times C_{t}
\end{gathered}
$$

where $\mathrm{P}$ and $\mathrm{ET}$ are respectively the rainfall and the evapotranspiration, $E_{t}, M_{t}$ and $C_{t}$ are the water levels in the Epikarst, Matrix, and Conduit reservoirs respectively, $k_{A B}$ is the recession coefficient associated to the flow from reservoir A (either E, M, or C) to reservoir B (either M, C, or S) or to the outlet $\mathrm{S}$, and $Q_{A B}$ is the discharge [L/T] from $\mathrm{A}$ to $\mathrm{B}$. Discharge in $\mathrm{L}^{3} / \mathrm{T}$ is computed by the product of $Q_{A B}$ with the total surface of the recharge area $\left(\mathrm{R}_{\mathrm{A}}\right)$.

The rainfall-discharge model was calibrated using a quasi Monte-Carlo procedure with a Sobol sequence sampling of the parameter space. 


\subsection{Modeling strategy}

To built a rainfall-discharge model, three periods must be taken into account. The warm-up period corresponds to the time interval after which the initialisation bias is deemed negligible. Simulation results from this period were not considered in the calibration. Mazzilli et al. (2012) showed that the initial water level in a linear reservoir with a low recession coefficient has a relatively low influence on the simulated discharge but it decreases slowly. In a reservoir with a high recession coefficient, the initial water level has a relatively high influence on the simulated discharge but it decreases quickly. In this study, we started the warm-up period at the end of the low flow period (15th October 2012) at the beginning of the time series available. The warm-up period was set at 69 days (until 22nd December 2012) and included several floods. The second period is the calibration period. It corresponds to the time interval over which the optimal parameter set is tested. This period ran from 23rd December 2012 to 18 th October 2013 so as to cover almost one year and low and high water periods. Finally, the validation period corresponds to the time interval over which the model performance is evaluated, from 19th October 2013 to 26th January 2016 (latest data available).

We ran the KarstMod platform for several simulations to get the best set of 7 parameters. The simulation began on 15 th October 2012, in a low flow period. Nevertheless, a few days before (11th October 2012) there were about $40 \mathrm{~mm} /$ day of precipitations. We assigned an arbitrary value of $30 \mathrm{~mm}$ for $\mathrm{E}_{0}$ and $\mathrm{M}_{0}$, the initial water levels for the Epikarst and Matrix reservoirs, using a warm-up period long enough to render the influence of the initial conditions negligible. The initial water level in the Conduit reservoir, $\mathrm{C}_{0}$, was set at $0 \mathrm{~mm}$, considering that the Conduit reservoir should be empty at the end of the low flow period and decreases very quickly in the case of a previous rain event. We attributed a range of values between -30 and $0 \mathrm{~mm}$ for $E_{\min }$ to represent the potential water storage in the soil. The $\mathrm{E}_{\text {ThresholdC }}$ can range between 10 and $50 \mathrm{~mm}$. The results for this configuration will be used and detailed in the following parts of this paper. However, we also conducted a split sample test, using the previous validation period as the calibration period and vice- versa. The results will not be detailed in this paper, but were very close to the first configuration, showing that there is no influence of the calibration and validation period chosen.

For each recession coefficient, we selected a range of possible values within two orders of magnitude in order to have a large range and to better observe the sensitivity of each coefficient. The recession coefficient between the Epikarst and Matrix reservoirs, $k_{E M}$ ranges between $10^{-2}$ and $1 \mathrm{~d}^{-1}$. Regarding flow to the Conduit reservoir, the $k_{E C}$ coefficient ranges between $10^{-1}$ and $10^{1} \mathrm{~d}^{-1}$. Moreover, the recession coefficient between the Matrix reservoir and the spring, $k_{M S}$ ranges between $10^{-3}$ and $10^{-1} \mathrm{~d}^{-1}$ to simulate a slow discharge in the matrix. The recession coefficient from the Conduit reservoir to the spring, $k_{C S}$, ranges between $3 \times 10^{-1}$ and $3 \mathrm{~d}^{-1}$ to simulate a fast flow in karst conduits. The value of the recharge area $\left(\mathrm{R}_{\mathrm{A}}\right)$ ranges between 50 and $70 \mathrm{~km}^{2}$ in order to respect geological knowledge. The reservoir model was established at the global scale, on the assumption that the entire area contributes equally to the discharge at the spring.

\subsection{Model performance}

The performance criteria proposed in KarstMod are the Nash-Sutcliffe efficiency coefficient NSE (Nash and Sutcliffe, 1970) and the modified Balance Error BE, defined as follows:

$$
\begin{gathered}
N S E=1-\frac{\Sigma\left(Q_{o b s}-Q_{\text {sim }}\right)^{2}}{\Sigma\left(Q_{o b s}-Q_{\text {mean }}\right)^{2}} \\
B E=1-\left|\frac{\sum\left(Q_{o b s}-Q_{\text {sim }}\right)}{\sum Q_{o b s}}\right|
\end{gathered}
$$

where $Q_{\text {obs }}$ is the observed discharge $\left(\mathrm{m}^{3} / \mathrm{s}\right) ; \mathrm{Q}_{\text {sim }}$ is the simulated discharge $\left(\mathrm{m}^{3} / \mathrm{s}\right) ; \mathrm{Q}_{\text {mean }}$ is the average observed discharge $\left(\mathrm{m}^{3} / \mathrm{s}\right)$.

NSE and BE range from $-\infty$ to 1 . An NSE of 1 is a perfect match between model and observations. An NSE of 0 indicates that the model performs equally to the mean of the observed data. For NSE $<0$, the mean is a better predictor than the model. A BE of 1 means that the total simulated volume discharged at the outlet is equal to the total volume observed. The KarstMod platform uses an aggregated objective function defined as the weighted sum of the two performance criteria, according to equation (5):

$$
W o b j=w N S E+(1-w) B E
$$

with Wobj the objective function, and w the weight defined by the user $(0 \leq \mathrm{w} \leq 1)$. We used the aggregated objective function and kept $w=0.6$ among several tested solutions for $\mathrm{w} \geq 0.5$ (not presented here), i.e., with a higher weight on the NSE criteria in order to first reproduce the highly dynamic behavior of the karst, and second to minimize the volume error.

We assigned a Wobj minimum at 0.7 to obtain a strong performance of the model. We selected 10000 simulations with a performance criteria $W o b j>0.7$. All the simulations are graphically represented in Figure 6. The parameter set associated with the highest performance criteria was kept and used to draw the simulated discharge curve on Figure 7. KarstMod also proposes to use the simulation results from all the parameter sets yielding $W_{o b j}>0.7$ for the evaluation of the uncertainty on the simulation results. The approach is derived from the Regional Sensitivity Analysis (Hornberger and Spear, 1981) and the Generalized Likelihood Uncertainty Estimation (GLUE) (Beven and Binley, 1992). Instead of selecting a unique parameter set as the outcome of the calibration process, these methods consider that all parameter sets yielding satisfactory results over the calibration period (behavioral parameter sets) should be considered in the prediction process. The value of Wobj over the calibration period is used as a likelihood measure for each behavioral parameter set. The $90 \%$ confidence interval limits are also plotted in Figure 7 for the simulated discharge at time $t$, computed over the behavioral parameter sets using the likelihood as a weighting factor.

Moreover the KarstMod platform offers a sensitive analysis about the chosen parameters (Mazzilli et al., 2017). Indices are calculated using the Sobol procedure described in Saltelli (2002). The sensitivity indices are related to the decomposition of the variance of the calibration variable (here, discharge at the outlet) into terms that are due either to each 

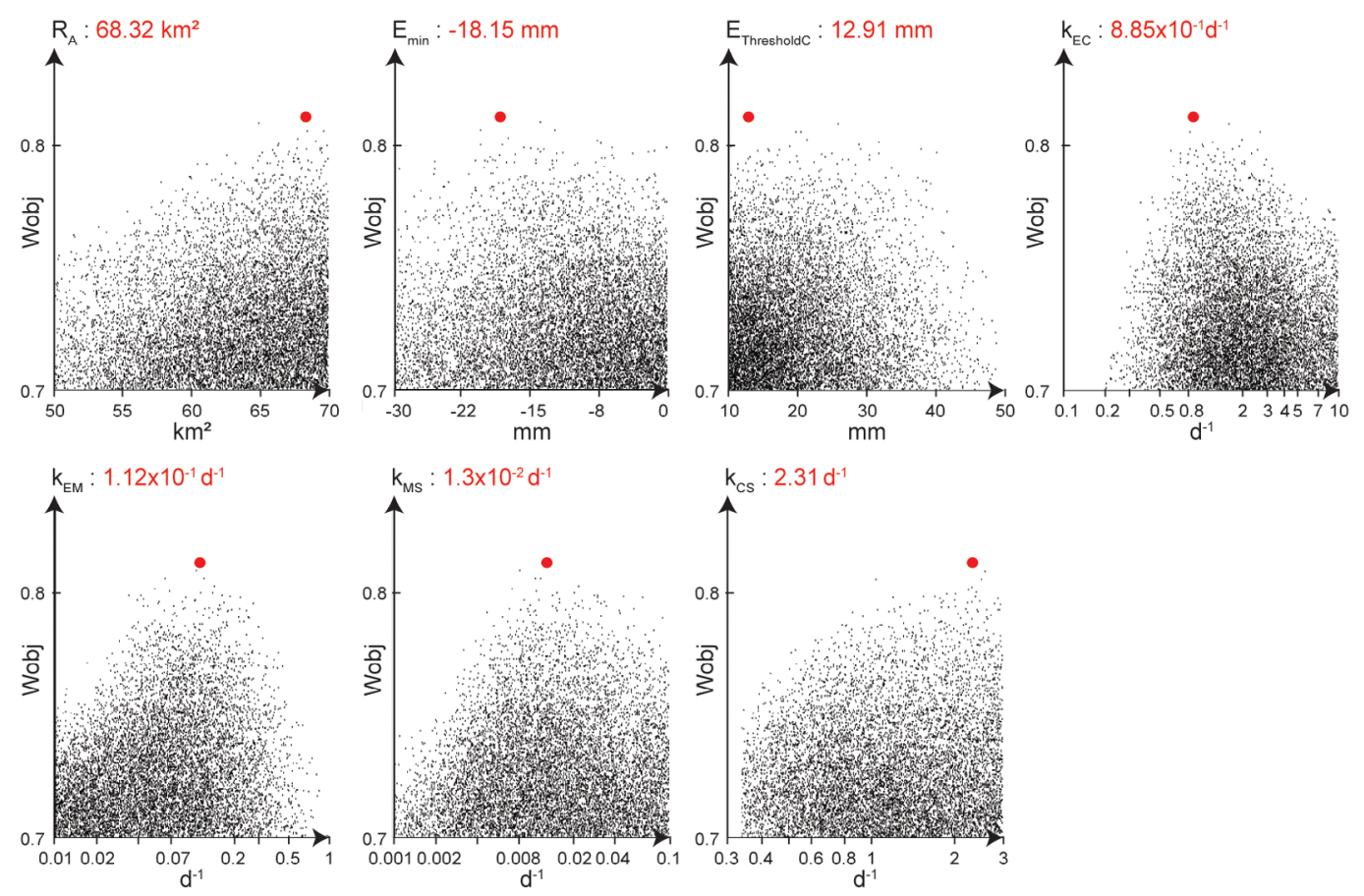

Fig. 6. Analysis of the sensitivity of the input parameters of the rainfall-discharge model with a Monte-Carlo procedure. Wobj=objective function. The best fit with the objective function chosen is marked by a red dot and the values of the parameter set are given above each graph.

parameter $i$ taken singularly (first order indices), or to interactions between parameters (total-effect index). The sensitivity index $S_{i}$ for parameter $X_{i}$ with respect to the simulated discharge $Q_{S}$ is defined as the fraction $V_{i}$ of the variance $\mathrm{V}\left(\mathrm{Q}_{\mathrm{S}}\right)$ of the simulated discharge, which is due solely to the parameter $\mathrm{X}_{\mathrm{i}}$ :

$$
S_{i}=\frac{V_{i}}{V_{Q s}}
$$

The total sensitivity index $\mathrm{S}_{\mathrm{Ti}}$ measures the contribution of $\mathrm{X}_{\mathrm{i}}$ to the output variance, including the interactions of $\mathrm{X}_{\mathrm{i}}$, of any order, with other input variables (Saltelli et al., 2008). By default, the sensitivity indices provided by KarstMod are obtained based on a $N=1000 \times\left(\mathrm{n}_{\text {par }}+2\right)$ parameter set, where $\mathrm{n}_{\mathrm{par}}$ is the number of parameters to be calibrated.

\subsection{Water level simulation}

In order to simulate the water level in the karst aquifer conduit network, a karst storage coefficient is introduced to transform the simulated water level in the Conduit reservoir following equation 7 :

$$
\text { Water Height } \text { simulated }=\frac{\text { Water level }}{\text { KarservoirC }}
$$

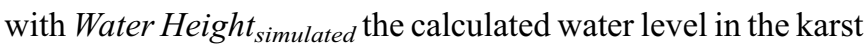
conduit network of the aquifer, Water level reservoir $C_{C}$ the water level in the Conduit reservoir simulated with the lumped rainfall-discharge model.
We previously showed that the water level in the Ragas is representative of the karst conduit network and is controlled by two hydraulic boundaries. The lower boundary is the dam's water level, controlled by the water supply factory. In order to be independent of the water supply control, we only used data during periods when the water level exceeded 123 m.a.s.l, i.e., when the lake was full with flow over the dam spillway. The upper boundary is the overflow threshold of the Ragas karst conduit, at 149 m.a.s.1, which limits the higher water level to a few meters above this value but is not included in the lumped model. This boundary will have a very limited effect on the results since this threshold was rarely exceeded at the daily time-step used for the model application. The karst storage coefficient was then calibrated during floods observed in the Ragas, selected for an initial water level close to 123 m.a.s.l.

\subsection{Quantification of baseflow and quickflow}

Separating the hydrograph of karst springs has been the subject of numerous studies over several decades, using recession analysis (e.g., Atkinson, 1977; Baedke and Krothe, 2001; Fiorillo, 2014; Fu et al., 2016; Geyer et al., 2008; Kovács and Perrochet, 2008; Kovács et al., 2005; Mangin, 1975; Padilla et al., 1994). Recession analysis can be applied at the flood scale or at the annual scale. At the flood event scale, the hydrograph can be separated by the sum of one, two or more recession curves (Fiorillo, 2014). As pointed out by Kovács and Perrochet (2008), the number of recession curves fitted is not necessarily representative of the number of media drained by the spring. The hydrograph separation is closely linked to the conceptual model of the aquifer behavior. 
a)
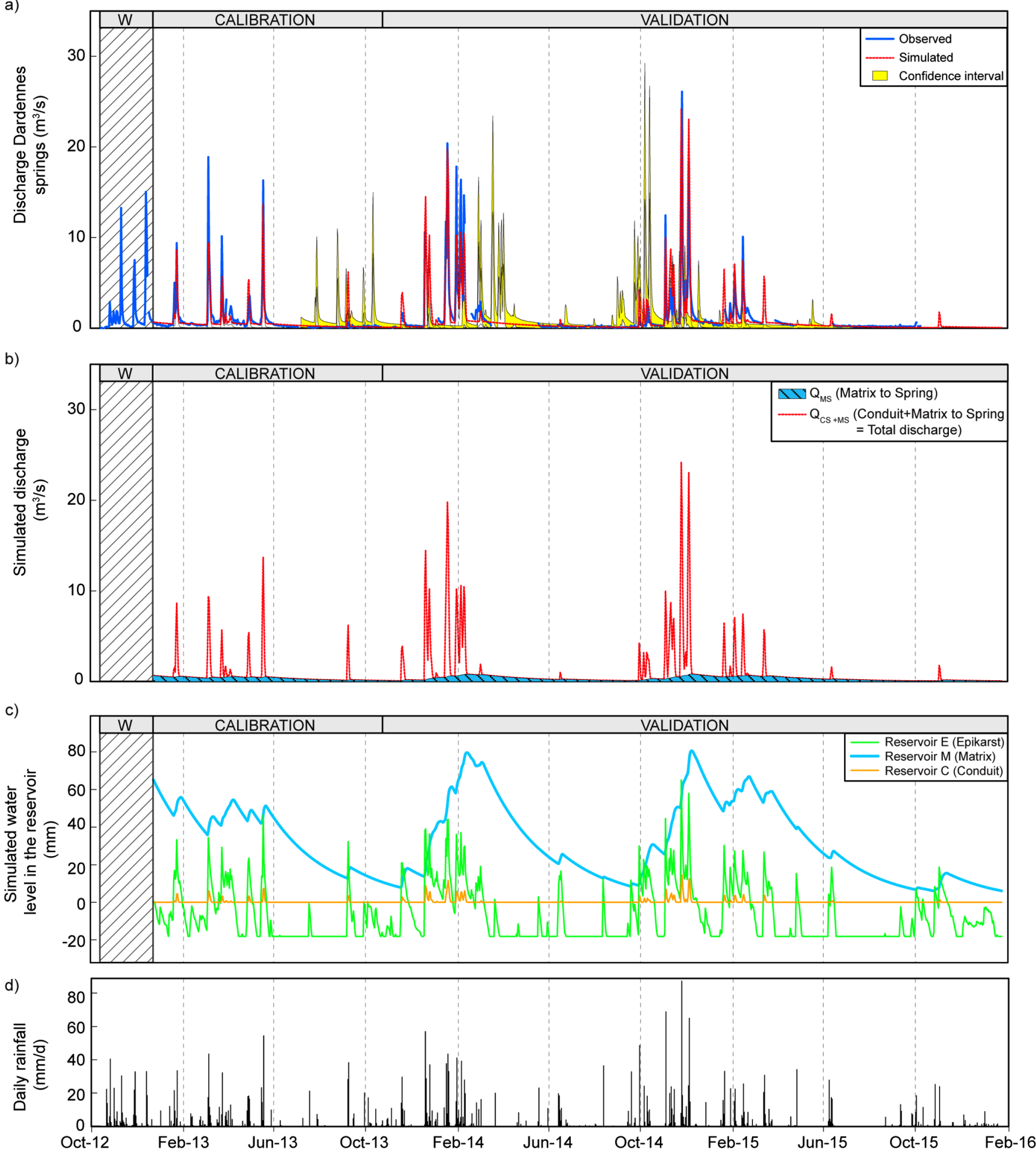

Fig. 7. Results of the model. $W=$ warm-up period. a) Observed and simulated discharge. b) Internal simulated discharges: from the Matrix reservoir to the spring and total discharge to the spring (Matrix + Conduit reservoirs). c) Simulated water level in the three reservoirs E, M and C. d) Daily rainfall (average of the three rain gauges). 
Table 1. Calibration values of the model parameters.

\begin{tabular}{llll}
\hline Parameter & & Unit & Calibration \\
\hline $\mathrm{R}_{\mathrm{A}}$ & Recharge area & 68.32 \\
$\mathrm{E}_{\mathrm{min}}$ & Minimum water level in reservoir E (Epikarst) & $\mathrm{km}^{2}$ & $\mathrm{~mm}$ \\
$\mathrm{E}_{\mathrm{ThresholdC}}$ & Threshold water level in reservoir E for flow to the Conduit reservoir (C) & $\mathrm{mm}$ & 12.91 \\
$\mathrm{k}_{\mathrm{EM}}$ & Recession coefficient of the reservoir E (flow to the Matrix reservoir) & $\mathrm{d}^{-1}$ & $1.12 \times 10^{-1}$ \\
$\mathrm{k}_{\mathrm{EC}}$ & Recession coefficient of the reservoir E (flow to the Conduit reservoir) & $\mathrm{d}^{-1}$ & $8.85 \times 10^{-1}$ \\
$\mathrm{k}_{\mathrm{MS}}$ & Recession coefficient of the Matrix reservoir (flow to the spring) & $\mathrm{d}^{-1}$ & $1.30 \times 10^{-2}$ \\
$\mathrm{k}_{\mathrm{CS}}$ & Recession coefficient of the Conduit reservoir (flow to the spring) & $\mathrm{d}^{-1}$ & 2.31 \\
\hline
\end{tabular}

Nonetheless, a karst spring hydrograph will be basically described by at least two components: a quickflow and a baseflow, with variable imprint depending on the case study (Ford and Williams, 2013). For instance, at the annual scale, Padilla et al. (1994) calculated the baseflow for four karst springs in France and Spain, finding a contribution of $100 \%$, $91 \%, 90 \%$ and $40 \%$ to the total groundwater drained by the springs. Fu et al. (2016) found that $25 \%$ of the discharge flows through the conduit network and $75 \%$ through the fracture and matrix (equivalent to baseflow). Results vary according to springs or karst aquifers, and to recharge events. The use of a lumped rainfall-discharge model offers new possibilities to make an automatic hydrograph separation at each time-step of the time series. It is then easy to give the varying relative proportion of baseflow and quickflow at different time scales (during floods, seasonal, annual or inter-annual). For this purpose, the model should be structured with a low flow component (Matrix reservoir) and a fast flow component (Conduit reservoir). The internal discharges $\mathrm{Q}_{\mathrm{MS}}$ and $\mathrm{Q}_{\mathrm{CS}}$ give respectively the baseflow and the quickflow.

\section{Results and discussion}

\subsection{Model calibration, validation and sensitivity}

The calibration values of the model parameters are given in Table 1 for the best result over the 10000 parameter sets using the aggregate objective function $(W o b j)$. According to the performance criteria shown in Table 2 and visual control of the simulated hydrograph shape, we assume that the simulated discharge is well fitted to the observed data. NSE is 0.72 in the calibration and 0.80 in the validation period. The modified balance error (BE) is close to 1 .

Table 3 gives the first-order and total-effect sensitivity indices. Total-effect sensitivity indices indicate the overall sensitivity of the model performance (assessed by the objective function) to the parameters, within the previously user-defined range of variations. The most sensitive parameters are $\mathrm{E}_{\text {ThresholdC, }} k_{E M}, k_{E C}$ and $k_{M S}$, while the least sensitive parameters are $\mathrm{E}_{\mathrm{min}}, k_{C S}$ and $\mathrm{R}_{\mathrm{A}}$. From a theoretical perspective, the low sensitivity of $E_{\min }$ suggests that the model structure should be changed by deleting Emin, with no impact on the objective function performance. However, we chose to keep $\mathrm{E}_{\min }$ in order to add a storage capacity in the epikarst. Conversely, the sensitivity to the recharge area was tested with Karstmod for several ranges (not presented in this study). It showed that sensitivity varied with ranges of $\mathrm{Ra}$ and the low sensitivity of the calibrated model is due to the
Table 2. Model performances for calibration and validation periods (NSE: Nash-Sutcliffe Efficiency, BE: Balance Error, Wobj: objective function).

\begin{tabular}{lll}
\hline Performance criteria & Calibration period & Validation period \\
\hline $\mathrm{NSE}$ & 0.72 & 0.80 \\
$\mathrm{BE}$ & 0.99 & 0.98 \\
Wobj $=0.6 \mathrm{NSE}+0.4 \mathrm{BE}$ & 0.83 & 0.88 \\
\hline
\end{tabular}

Table 3. Sensitivity indices (first-order index, total-effect index), ranks, and interactions index.

\begin{tabular}{llllll}
\hline Parameter & $\begin{array}{l}\text { First- } \\
\text { order } \\
\text { index }\left(\mathrm{S}_{\mathrm{i}}\right)\end{array}$ & $\begin{array}{l}\text { Total- } \\
\text { effect } \\
\text { index }\left(\mathrm{S}_{\mathrm{ti}}\right)\end{array}$ & $\begin{array}{l}\text { Rank } \\
\mathrm{S}_{\mathrm{i}}\end{array}$ & $\begin{array}{l}\text { Rank } \\
\mathrm{S}_{\mathrm{ti}}\end{array}$ & $\begin{array}{l}\text { Interactions } \\
\text { between } \\
\text { parameters : } \\
\left(\mathrm{S}_{\mathrm{ti}}-\mathrm{S}_{\mathrm{i}}\right) / \mathrm{S}_{\mathrm{ti}}(\%)\end{array}$ \\
\hline $\mathrm{E}_{\text {ThresholdC }}$ & 0.214 & 0.332 & 1 & 1 & 59.94 \\
$\mathrm{k}_{\mathrm{EC}}$ & 0.142 & 0.286 & 2 & 3 & 36.92 \\
$\mathrm{k}_{\mathrm{MS}}$ & 0.135 & 0.214 & 3 & 4 & 50.35 \\
$\mathrm{k}_{\mathrm{EM}}$ & 0.125 & 0.312 & 4 & 2 & 35.54 \\
$\mathrm{E}_{\text {min }}$ & 0.035 & 0.116 & 5 & 5 & 73.33 \\
$\mathrm{k}_{\mathrm{CS}}$ & 0.032 & 0.120 & 6 & 6 & 69.83 \\
$\mathrm{R}_{\mathrm{A}}$ & 0.021 & 0.067 & 7 & 7 & 68.66 \\
\hline
\end{tabular}

relatively low range of variation we allowed (based on geological knowledge).

The last column of Table 3 gives insight into interactions between parameters. The most linked parameter is $\mathrm{E}_{\min }$, probably due to interactions with $\mathrm{E}_{\mathrm{ThresholdC}}$ and $\mathrm{R}_{\mathrm{A}}$. Indeed, the more negative $\mathrm{E}_{\min }$ is, the higher the available water height for evapotranspiration is, which induces a higher $\mathrm{R}_{\mathrm{A}}$ to reduce the balance error. Less linked parameters are $k_{E M}$ and $k_{E C}$, which govern the relative amount of flow to the lower reservoirs. However, even these are not fully independent: increasing $k_{E C}$ or lowering $\mathrm{E}_{\text {ThresholdC }}$ (while keeping $k_{E M}$ constant) will also decrease the amount of water that infiltrates to reservoir $\mathrm{M}$.

Figure 6 shows, for each parameter calibrated, the scatterplot of the values of the objective function (calibration period) against the values of the parameter, for all parameter sets of the Sobol sequence that satisfy $W_{o b j}>0.7$. In an equifinality analysis, these plots show that the model has found an optimum for the calibration. The first scatterplot on Figure 6 shows the best value found for the recharge area $\left(R_{A}\right)$. The best 
a) Discharge Dardennes springs $\left(\mathrm{m}^{3} / \mathrm{s}\right)$

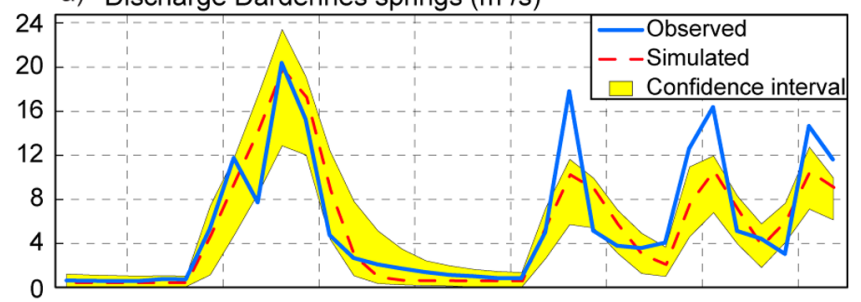

b) Simulated discharge $\left(\mathrm{m}^{3} / \mathrm{s}\right)$

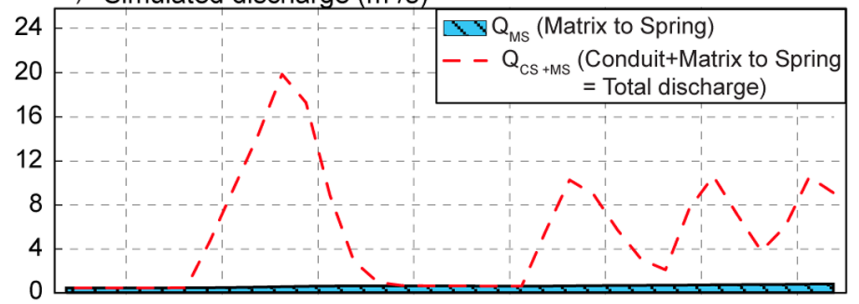

c) Simulated water level in the reservoir $(\mathrm{mm})$

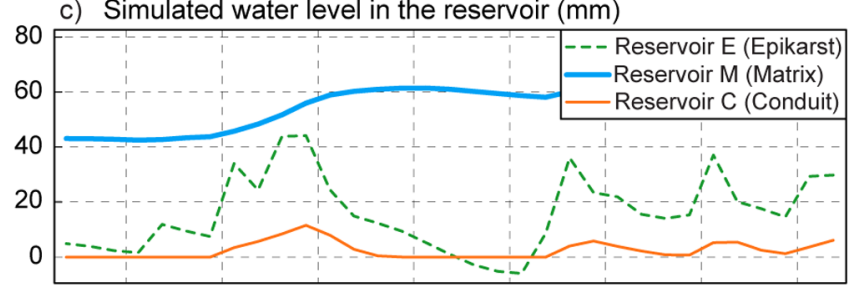

d) $\%$ of simulated discharge

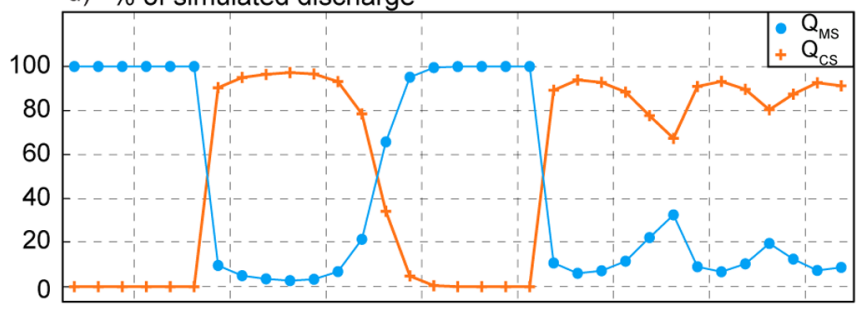

e) Daily rainfall $(\mathrm{mm} / \mathrm{d})$

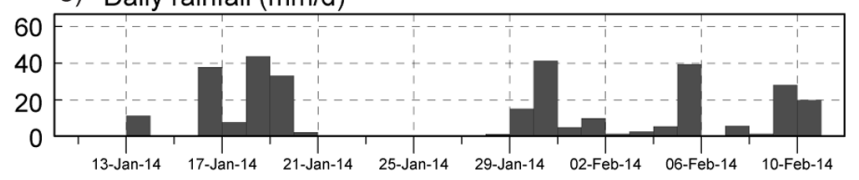

Fig. 8. Floods of January and February 2014. a) Simulated discharge of the Dardennes springs, b) Internal simulated discharges: from the Matrix reservoir to the spring and total discharge to the spring (Matrix + Conduit reservoirs) c) Simulated water level in the three reservoirs E, M and C, d) Percent of simulated discharge for QMS (flow from reservoir $\mathrm{M}$ to the spring: baseflow), and QCS (flow from reservoir C to the spring: fast flow), e) Daily rainfall (average of the three rain gauges).

value is close to $70 \mathrm{~km}^{2}$, confirming that a good simulation can be achieved using the range of recharge area given by geological analysis. The scatterplot for $\mathrm{E}_{\min }$ shows a sill between -20 and $0 \mathrm{~mm}$, which means that regardless of the values (within this range), the model converged to a Wobj maximum by adapting the parameter sets. This parameter does not have a strong influence on the lumped-model calibration (Tab. 3). The scatterplot for $\mathrm{E}_{\text {ThresholdC }}$ (threshold water level in reservoir $\mathrm{E}$ for flow to reservoir $\mathrm{C}$ ) shows a rough optimum between 10 and $30 \mathrm{~mm}$. This parameter has a great influence on the separation of the flow between slow (or matrix) and fast (or conduit) components because if the threshold is not reached the water will only recharge the Matrix reservoir (M) or be available for evapotranspiration (ET). The graphs for $\mathrm{k}_{\mathrm{EC}}, \mathrm{k}_{\mathrm{EM}}$ and $\mathrm{k}_{\mathrm{MS}}$ show a "bell" shape and an optimum value at the top of the bell. The optimum parameter set calibrated by the model is shown by the red dots in Figure 6 (given in Tab. 1) and is located in an acceptable range of possible values for each parameter.

\subsection{Dardennes karst aquifer functioning}

This study gives insight into the functioning of the Dardennes aquifer. First, the rainfall-discharge model confirms the range of the recharge area deduced from the geomorphological and geological study; the simulations are acceptable between 55 and $70 \mathrm{~km}^{2}$ (Fig. 6). However, the sensitivity indices (Tab. 3) show that this parameter is not very sensitive to the value chosen and that it cannot be specified more precisely. Second, the good results of the lumped model validated the conceptual model of the functioning of the aquifer. The aquifer functioning can be simplified by two main flow components from the epikarst to the springs: slow and fast flow components. Furthermore, the rainfall is separated in a soilepikarst compartment between a reserve available for evapotranspiration, the infiltration to supply the slow flow (Matrix reservoir) and the fast flow (Conduit reservoir).

Figure 7 a shows the simulated and observed discharge time series for the calibration and validation periods. The general shape of the discharge time series is well reproduced both for low flow periods and for dynamic variations during floods. The baseflow is well simulated with a long recession tail during the low flow period in summer and early autumn. During rainfall events, each observed flood peak is simulated by the lumpedmodel even if the maximum discharge simulated is not always accurate. At the end of the low flow period, mainly in September and October, the model mitigates the rainfall transfer to the spring by filling the Epikarst reservoir up to the $\mathrm{E}_{\text {ThresholdC, but the storage is insufficient and the simulated }}$ floods remain too high compared to the observed discharge. This shows that the impact of the first rainfall events is actually mitigated in the epikarst and in the aquifer. The rainfall infiltrated may be stored in the aquifer to fill up the groundwater reserve in the vadose zone. Furthermore, the storage can be increased by the variable head boundary controlled by the water level of the Dardennes lake regulated by the dam. The variation of the water level in the aquifer in relation to the water level variation in the lake is not taken into account in the lumped model.

\subsubsection{Baseflow and quickflow at the annual scale}

The separation hydrograph according to the two reservoirs Matrix (baseflow) and Conduit (quickflow) is presented on Figure $7 \mathrm{~b}$. The discharge from the Matrix reservoir to the spring shows a smooth and seasonal variation, and a long recession tail. The discharge from the Conduit reservoir to the spring increases and decreases very quickly over a few days. Table 4 gives the baseflow and quickflow rates at the annual scale. During the three years studied, on average from 1st January 2013 to 31 st December 2015, 64\% of the infiltrated 
Table 4. Annual mean and percent of: $\mathrm{Q}_{\mathrm{MS}}$, the discharge flow from the Matrix reservoir to the spring, and $\mathrm{Q}_{\mathrm{CS}}$ the discharge flow from the Conduit reservoir to the spring. The rainfall column gives the mean precipitation calculated by averaging data from the three weather stations (Toulon, Le Castellet, Limate).

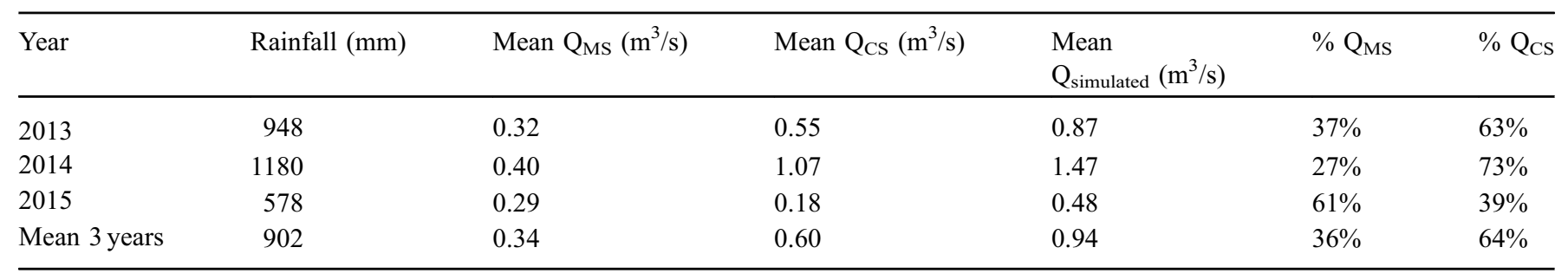

water flows through the fast reservoir and 36\% through the slow reservoir to the spring. In 2013, the percentages are almost the same as over the whole study period. But in 2014, during a rainy year (1180 $\mathrm{mm}$ of rain), the quickflow is very dominant with $73 \%$ of the total simulated discharge, with a mean $\mathrm{Q}_{\mathrm{CS}}$ of $1.07 \mathrm{~m}^{3} / \mathrm{s}$ compared to a mean $\mathrm{Q}_{\mathrm{MS}}$ of $0.40 \mathrm{~m}^{3} / \mathrm{s}$. During the dry year in 2015 (with only $578 \mathrm{~mm}$ of rainfall), in contrast, the baseflow is most important representing $61 \%$ of the total simulated discharge. The drier the year is, the higher the baseflow proportion is, but the lower the baseflow value. Over the three years, the baseflow was almost constant, between 0.29 and $0.40 \mathrm{~m}^{3} / \mathrm{s}$, showing that the baseflow is a stable component in the Dardennes aquifer.

\subsubsection{Baseflow and quickflow at the flood scale}

Figure $8 \mathrm{~d}$ shows the proportion of baseflow and quickflow at a flood event scale, during the five floods that occurred in January and February 2014 (Fig. 4 and Fig. 7). Before these events, the simulated discharge flows only from the Matrix reservoir ( $100 \%$ of baseflow $\mathrm{Q}_{\mathrm{MS}}, 0 \% \mathrm{Q}_{\mathrm{CS}}$, Fig. 8). In one day, the trend is reversed, the proportion of quickflow increases drastically, reaching a maximum of $97 \%$ at the flood peak. For six days, the quickflow rate remains high, above $90 \%$.

As the water is not stored in the Conduit reservoir of the lumped model, the peak flow at the spring is highly correlated to the amount of rainfall recharged in the aquifer, with more than $90 \%$ of the rain infiltrated transferred as flood volume. However, the lumped model provides no insight into the origin of the flood water at the spring. A further analysis is needed, using geochemical tracers, to investigate the groundwater origin, either by the piston effect of pre-event groundwater or by mixing with infiltrated event water. This very high contribution of rainfall to the quickflow shows that the aquifer must be highly transmissive, through a well-connected karst network. Nonetheless, the baseflow remains high, around $0.34 \mathrm{~m}^{3} / \mathrm{s}$ on average at the annual scale (Tab. 4), showing the non-negligible storage and flow in the matrix.

According to our initial conceptual model applied in the lumped model, the quickflow generates floods and does not increase the groundwater storage. This is probably almost true during high-water periods, when there are several floods that follow, therefore the quickflow is the main discharge at the spring $\left(\mathrm{Q}_{\mathrm{CS}}\right)$ and the low flow part of the recharge $\left(\mathrm{Q}_{\mathrm{EM}}\right)$ increases the groundwater storage (water level increases in the matrix). Nevertheless, we previously showed that the groundwater recharge at the end of the low-flow period is stored in the aquifer matrix at a higher rate and therefore mitigates the floods. This is not included in the lumped model. The quantitative aspect of this storage was not investigated in this study; however, it may slightly impact the baseflow and quickflow rate evaluation at the annual scale, as only part of the quickflow for some floods is actually stored in the matrix.

\subsubsection{Interpreting reservoir parameters and internal water level}

Figure $7 \mathrm{c}$ shows the three internal water levels in millimeters during the study period. The Epikarst reservoir shows negative values due to the water level $E_{\min }$ that can be negative to represent the quantity of water available for evapotranspiration (calibrated $\mathrm{E}_{\min }=-18.15 \mathrm{~mm}$ ). Its water level varies depending on precipitation events. When the water level is above $0 \mathrm{~mm}$ in the Epikarst reservoir, the aquifer recharge becomes effective and supplies the Matrix reservoir and therefore the baseflow. This baseflow is provided by the vadose zone, which is several hundred meters thick on the Siou Blanc plateau (Fig. 1) and by the slow flow in the matrix in the saturated zone drained by the well-connected karst network to the springs. If the Epikarst reservoir water level exceeds the $\mathrm{E}_{\text {Thresholdc }}$, calibrated to $12.91 \mathrm{~mm}$, the quickflow is activated. The water level in the Conduit reservoir increases and returns to zero very quickly, as expected with the high recession coefficient $\left(k_{E C}\right.$ and $\left.k_{C S}\right)$ and the threshold in reservoir $\mathrm{E}$. The Matrix reservoir has a larger amplitude variation than the others, with seasonality since it is filled during the rainy period when the level in reservoir $\mathrm{E}$ is above zero, and the water level in $\mathrm{M}$ decreases slowly with a low recession coefficient $\left(k_{M S}\right)$. The $k_{E C}$ recession coefficient is so high (Tab. 1), that above the threshold $\mathrm{E}_{\text {ThresholdC }}$, the Epikarst reservoir water is transferred to the Conduit reservoir in a few time steps and therefore is no longer available to supply the baseflow (Matrix reservoir). Thus, whether the rain is of low or high intensity, the discharge that supplies the baseflow remains about the same (as shown in the previous section).

The Dardennes springs evidence a highly dynamic karst aquifer functioning, with $k_{C S}$ higher than $1 \mathrm{~d}^{-1}$. This very high recession coefficient suggests a karst aquifer with a wellconnected and organized karst network. It enables very high flash floods at the spring outlet, with high peak discharge that will contribute to stream flash floods downstream.

\subsubsection{Simulating karst water level}

In addition to the rainfall-discharge modeling, we compared the water level simulated in the Conduit reservoir 

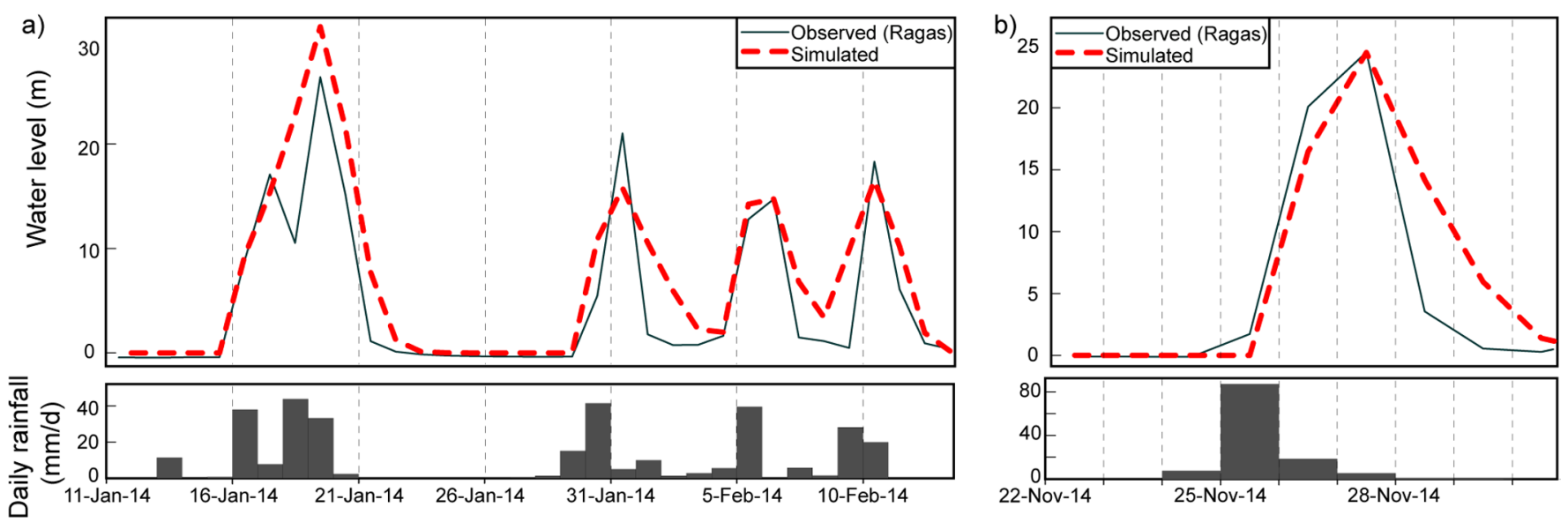

Fig. 9. Observed water level (daily average) in the Ragas above the lake water level (zero reference is equivalent to $123 \mathrm{~m}$ of in situ elevation), when the Dardennes lake overflows by the dam spillway. Simulated water level of the reservoir C converted in height of water level above $123 \mathrm{~m}$. a) Floods of January and February 2014 (with karst storage $=3.6 \times 10^{-4}$ ) b) Flood of 26th November $2014\left(\right.$ with karst storage $=5.7 \times 10^{-4}$ ) .

and the water level observed in the Ragas karst conduit using equation 7 . We chose the floods of January and February 2014 (Fig. 9a) and November 2014 (Fig. 9b) as examples because: i) the discharge of the floods is well simulated by the model (Fig. 7a) and ii) the water level in the lake is constant (123 m.a. s.l) and can be used as a constant base-level to calculate the water height increase during the floods. To graphically fit the simulated water height to the observed water level, the karst storage was set at $3.6 \times 10^{-4}$ for the January and February 2014 flood events, and at $5.7 \times 10^{-4}$ for the 25 th November 2014 flood. The calibrated karst storage value is 10 to 100 fold smaller than the effective porosity given in the literature with a similar method, e.g., for the well documented Lez karst aquifer (France) the value is about $3 \times 10^{-3}$ under withdrawal conditions (Fleury et al., 2009; Mazzilli et al., 2011; Roesch and Jourde, 2006) and Fu et al. (2016) found about $3 \times 10^{-2}$ for a small catchment area of $1.14 \mathrm{~km}^{2}$ in Carboniferous rocks. The water level variation and the dynamic of the floods are well simulated, showing that the Conduit reservoir of the model is able to represent the quickflow through the karst network in the aquifer as observed in the Ragas karst conduit.

\subsection{How has geological evolution structured the aquifer?}

The fast and significant variation in the water level of the Ragas conduit, and the high percentage of quickflow during floods, show that the Dardennes aquifer is a very dynamic karst. We explored how such an aquifer behavior can be possible. The answer lies in a combination of geological and geomorphological factors. First, the recharge has to be concentrated and not diffuse to allow a large quantity of water to infiltrate rapidly (Audra and Palmer, 2013). Field observations showed that there is no permanent river nor temporal lake in the springs' recharge area. High intensity rainfall events induce runoff to fast infiltration points such as vertical shafts, or sinkholes. There is no thick soil and no impervious cover. Second, the water transfer within the vadose and the saturated zone has to be very quick through well- connected vertical and horizontal pipes. The Dardennes aquifer is composed of early Cretaceous rocks, known as Urgonian facies, and late Jurassic rocks, dolomite and limestones (Fig. 1). The Urgonian facies rocks are very tight, with a very low intergranular porosity (Leonide et al., 2014), and with mainly porosity and permeability in karstified vertical faults and fractures. These fractures have been recognized across the carbonate Jurassic and Cretaceous rocks. Late Jurassic rocks can also be karstified with ghost rocks (Dubois et al., 2014) in the deep part of the aquifer, as observed in the current vadose zone. The whole aquifer is then cross-cut by karst features forming an extensive interconnected karst network. According to the rainfall-discharge model, the karst storage coefficient calculated on several floods is about $4.4 \times 10^{-4}$ over the whole period studied, for the elevation $123 \mathrm{~m}$ to $149 \mathrm{~m}$, i.e., the range of investigation in the Ragas water level variation. This low value is characteristic of the karstic porosity of the aquifer. The tight Urgonian rocks may play the role of an impervious layer except in the karst conduits network. The Dardennes aquifer is then separated between an unconfined water table in the early Cretaceous and a confined water table in depth, in the late Jurassic, connected to the Dardennes springs by a deep rising shaft.

Furthermore, the Dardennes springs are located between a northern monocline domain and the major overthrust zone (Fig. 1). In complex geological areas, the role of tectonic structures on karst groundwater flows has been identified by field observations and tracing experiments (Häuselmann et al., 1999; Herold et al., 2000; Levens et al., 1994). Fault zones can act as barriers to stop groundwater flow or as conduits that drain fluids (Caine et al., 1996) or even as complex conduitbarrier systems (Matonti et al., 2012). The geological Toulon area is the result of several tectonic phases that have conditioned the current aquifers. The Pyrenean-Provence compression led to major thrust zones in this area (Bestani et al., 2015). The impervious basement is implicated in thrust structures and acts as a main barrier to groundwater flow, rising-up near the surface. Therefore, the groundwater is stored upstream this thrust zone and is forced to overflow above the 
thrust barrier. The impervious thrust zone can also stop the saline intrusion. So, even if the aquifer is several hundred meters deep below sea level, the groundwater remains fresh. This wide saturated zone of the aquifer below the springs gives a high groundwater storage, and a high reserve for groundwater supply.

\subsection{Predictions of flood discharge during an exceptional rain event}

The previous analysis showed the dynamic of the Dardennes karst system and the good results of the lumped rainfall-discharge model. The calibrated model was then used to predict discharge of a flood during an exceptional Mediterranean rain event. Over the study period, only one event reached $80 \mathrm{~mm} / \mathrm{d}$ (Fig. 7). However, in the Mediterranean climate, daily rainfall up to $300 \mathrm{~mm} / \mathrm{d}$ and more is known (Gaume et al., 2009; Meteo-France, 2017a), as shown by the 15 th June 2010 event in Draguignan city located $60 \mathrm{~km}$ northeast from Dardennes (Meteo-France, 2017b; Ruin et al., 2014). This rain event (minimum $270 \mathrm{~mm} / \mathrm{d}$ ) caused material and human damage. The Dardennes area will sooner or later be faced with an intense Mediterranean rain event. An artificial rain event was therefore inserted in the observed rainfall time series. As the intense Mediterranean events occur usually in spring (May or June) or in autumn (September to December), we ran the calibrated lumped model as previously done (Fig. 7), with the artificial rain event inserted on 15th May 2015. The initial conditions were the simulated values previously presented in Figure 7 (on 14th May 2015: $\mathrm{E}_{0}=\mathrm{E}_{\min }, \mathrm{C}_{0}=0 \mathrm{~mm}, \mathrm{M}_{0}=33.58 \mathrm{~mm}$, observed $\mathrm{ET}=5.7 \mathrm{~mm} / \mathrm{d}$ ).

The daily discharge at the Dardennes springs resulting from the artificial rain event is presented on Figure 10. Two cases were simulated: Case I, the Epikarst reservoir is empty on 14th May $2015\left(\mathrm{E}=\mathrm{E}_{\min }\right)$; Case II, the Epikarst is recharged and saturated the previous day by $30 \mathrm{~mm}$ of rain.

Three rain events were tested, with three model runs, and results are plotted in a single figure for each case. According to the lumped model, with respectively a rain event of $100 \mathrm{~mm} / \mathrm{d}, 200 \mathrm{~mm} / \mathrm{d}$ or $300 \mathrm{~mm} / \mathrm{d}$, the daily discharge peak will reach about $15 \mathrm{~m}^{3} / \mathrm{s}, 42 \mathrm{~m}^{3} / \mathrm{s}$ or $68 \mathrm{~m}^{3} / \mathrm{s}$ in case I, and $21 \mathrm{~m}^{3} / \mathrm{s}, 48 \mathrm{~m}^{3} / \mathrm{s}$ or $74 \mathrm{~m}^{3} / \mathrm{s}$ in case II. The three rain events generate a flash-flood, with the discharge peak only one day after the rain. In two days, the discharge decreases sharply, and the fast flow (Conduit reservoir) stops in four or five days. The rain also recharges the Matrix reservoir and so increases the slow flow. The falling recession curve of the hydrograph corresponds mainly to the discharge of slow flow. The model shows that in the case of an extreme rainfall event, the karst aquifer will transfer the rainfall input over the groundwater recharge area. It will generate a karst flash flood to the Las river, the small Mediterranean stream that flows through Toulon. Flash floods have already been observed in this stream with a contribution of karst or urban runoff depending on the rainfall events (Arfib et al., 2016). The contribution of the karst can then be a source of water, increasing the flood in the stream and hazard consequences, as was observed for instance in another Mediterranean karst system studied by Maréchal et al. (2008).
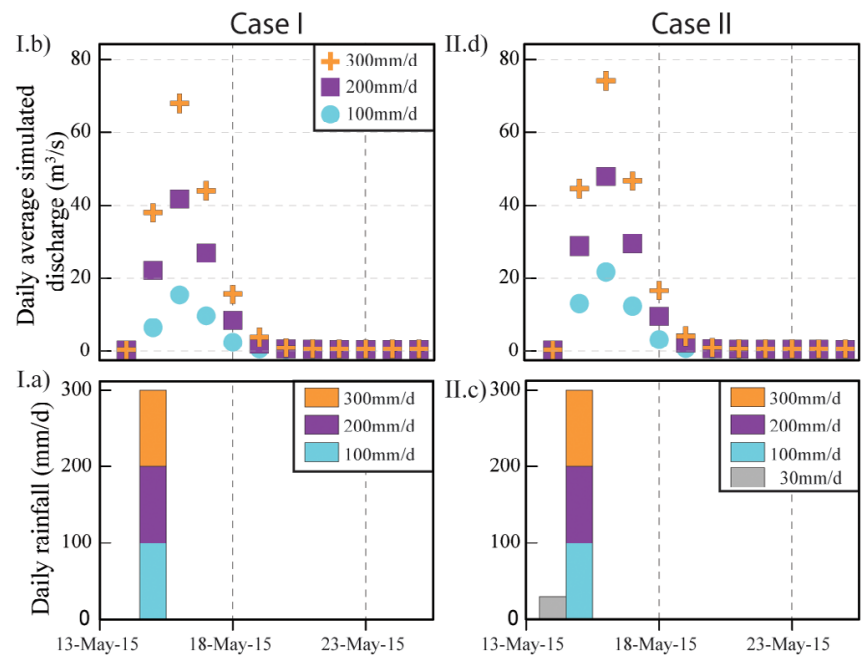

Fig. 10. Use of the calibrated rainfall-discharge model to predict the discharge in the case of an exceptional one-day rainfall event inserted in the time-series on 15th May 2015 (3 tests: $100 \mathrm{~mm} / \mathrm{d}, 200 \mathrm{~mm} / \mathrm{d}$ or $300 \mathrm{~mm} / \mathrm{d})$. Case I: the Epikarst reservoir is empty on 14th May 2015 $\left(\mathrm{E}=\mathrm{E}_{\min }\right)$. Case II: the Epikarst is recharged and saturated the previous day (rain $=30 \mathrm{~mm}$ on 14 th May 2015).

The validation of these results has some limits. Firstly, the rainfall-discharge model was calibrated for a maximum observed rain event of $80 \mathrm{~mm} / \mathrm{d}$, and no validation data are yet available for higher rainfall. Second, in the first case the low initial water level in reservoir $\mathrm{E}$ mitigates the flood, from $\mathrm{E}_{\text {min }}$ to $\mathrm{E}_{\text {ThresholdC }}$ (calibrated values $\mathrm{E}_{\text {ThresholdC }}-\mathrm{E}_{\min }=$ $31.06 \mathrm{~mm}$ ), whatever the rainfall amount, but the rate of this influence decreases as the amount of rainfall increases. Third, the karst network geometry (like the Ragas cave) may restrict the aquifer discharge in high flow with substantial turbulent head losses that can limit the maximum discharge and extend the flood duration. Or, otherwise, during the high water level stage some by-pass flow paths may be activated to facilitate a very fast transit. Fourth, this study already showed that the model overestimates the peak flow at the end of the low-flow period. It follows that an exceptional rainfall event will then be more mitigated by the natural storage in the aquifer depleted at the end of the summer than in the spring season. But in any case, if two equivalent rain events succeed each other, the second will be higher.

To go further in the flood prediction in this dynamic karst aquifer, the discharge and water level variations should be investigated at a lower time-step adapted to the variation velocity, e.g., at an hourly time-step. Indeed, the daily mean discharge reduces the real maximum peak discharge. The previous peak flow simulated should be taken as a minimum flood peak discharge value in the case of intense rainfall. Moreover, the spatial and time heterogeneities of the rainfall intensity were not taken into account.

\subsection{Groundwater management}

According to the conceptual model applied in the lumped model, the discharge from the Matrix reservoir to the spring simulates the baseflow. It gives an estimate of the groundwater 
Table 5. Comparison between the annual flow rate through the Matrix reservoir simulated with the rainfall- discharge model and the mean volume exploited by the drinking water supply factory.

\begin{tabular}{lll}
\hline Year & $\begin{array}{l}\text { Flow through } \\
\text { the conceptual } \\
\text { Matrix reservoir } \\
\text { (Millions } \mathrm{m}^{3} / \text { year) }\end{array}$ & $\begin{array}{l}\text { Mean volume } \\
\text { exploited } \\
\text { (Millions } \mathrm{m}^{3} / \text { year) }\end{array}$ \\
\hline 2013 & 10.1 & 6.7 \\
2014 & 12.1 & 6.0 \\
2015 & 9.2 & 4.8 \\
\hline
\end{tabular}

volume that flows naturally above the base level of the Dardennes aquifer. This volume represents the water available at the Dardennes springs, without pumping, for water supply. It does not take into account the extra volume stored in the Dardennes lake, nor the evaporation on the lake and the discharge released in the Las river for aquatic ecology. For the three years studied $(2013,2014,2015$, respectively normal, rainy and dry years), the volume discharged from the Matrix reservoir (Tab. 5) ranged from $9.2 \times 10^{6} \mathrm{~m}^{3} / \mathrm{y}$ in 2015 to $12.1 \times 10^{6} \mathrm{~m}^{3} / \mathrm{y}$ in 2014 . As pointed out in the previous section, the mean annual discharge $\mathrm{Q}_{\mathrm{MS}}$ (Tab. 4) varies little over the years. The volume exploited each year for water supply at the dam factory is also given in Tab. 5, ranging from 4.8 to $6.7 \times 10^{6} \mathrm{~m}^{3} / \mathrm{y}$. The exploited volume is therefore less than the half of the baseflow. At the annual scale, the groundwater tapping is sustainable, and there is still a water reserve available using part of the remaining baseflow or part of the fast flow that can be stored in the artificial lake of Dardennes. The natural baseflow in summer is not sufficient $(<100 \mathrm{~L} / \mathrm{s})$ and the water stored in the lake is needed to supply the demand (around $200 \mathrm{~L} / \mathrm{s}$ ). But the drinking water company is faced with a new problem: in the last few years, geosmin has developed in the surface water stored in the lake. The occurrence of geosmin in reservoirs and lakes is a common problem worldwide (Journey et al., 2013; Juttner and Watson, 2007) that causes taste-and-odor outbreaks in drinking water. This volatile organic compound (VOC) imparts a specific nasty earthy-muddy smell and taste to the water, reducing the use of surface water reservoirs. However, if there is no backflow of contaminated surface water, the groundwater is not affected by geosmin. It can then be an interesting alternative, even the only alternative, for water storage. Withdrawal of the groundwater during low flow periods requires pumping to tap the reserve, with a discharge rate higher than the baseflow. This can be achieved in the Dardennes case study by pumping in the Ragas deep karst conduit.

Active management of karst aquifers consists in optimally exploiting the groundwater resources, taking into account the impact on groundwater-surface stream exchanges and aquatic ecosystems in downstream rivers. It is a way to combine drinking water tapping, flood mitigation and ecology. The goal is to take advantage of the conduit network characterizing karst aquifers to pump a high flow rate in the low flow period and to store karst flash floodwater in the previously depleted voids. A high pumping rate will decrease the water table and dry up the connected springs to the karst network. It uses the groundwater reserve stored below the base level of the aquifer, i.e., below the level of the springs. It will fill up in the high water period, and mitigate intense floods at the beginning of the period (Jourde et al., 2013). This kind of management of karst aquifers is of increasing interest due to population growth in Mediterranean areas, which increases the fresh water demand and the need for protection against hazard impacts. This kind of water management is possible thanks to a hydrogeological context, which enables a good replenishment of the karst aquifer reserve during rainfall, after low flow periods (Bakalowicz, 2005; Fleury et al., 2009). Active management has been applied successfully for instance to the Lez aquifer in the south of France (Fleury et al., 2009).

Evaluating the potential for active groundwater management requires a combined analysis of the geological context and the hydrodynamic functioning of the karst aquifer as we previously did in the Dardennes case study. The Dardennes geological study showed that there is a large groundwater reserve in depth located below the outlet springs. Two geological structures support this observation: (1) the regional thrust structure forms a geological barrier to groundwater flow, preventing exchanges with the sea to the South, and forcing the groundwater to flow out in the Dardennes area; (2) below the Dardennes springs, the aquifer develops in depth with at least five hundred meters of permeable carbonate rocks. Moreover, this groundwater reserve is accessible by the Ragas karst conduit, which is at least 150 meters deep, and is well connected to the karst network draining the aquifer. The conceptual rainfall-discharge lumped model showed that high rain events recharge the matrix (slow flow) and conduits (fast flow). In the case of active management of the Dardennes aquifer, during the water level depletion period, the very fast infiltration will fill the conduit network up to the overflow elevation fixed by the dam spillway (123 m, Fig. 3). The water rapidly stored in the conduit network will then be able to flow to the surrounding less permeable matrix. Moreover, the Ragas natural overflow threshold, 26 meters above the dam $(149 \mathrm{~m}$, Fig. 3), increases the height of the karst network filled by fast flow during the floods, which increases the hydraulic gradient from conduits to matrix and the height of the epiphreatic zone. This water stored in the conduit network and the matrix will decrease the karst flash-floods in the Las river downstream, decreasing the flood hazard in Toulon. This effect will be even greater during the intense Mediterranean rainfall events occurring between September and November, when the water table should be at its lowest level. To explore these hypotheses, the rainfall-discharge model could be improved by taking into account the current water level in the Ragas decreasing below the $123 \mathrm{~m}$ dam spillway by pumping in the lake. An in situ pumping test in depth in the Ragas conduit would also improve our knowledge about this dynamic aquifer.

\section{Conclusion}

The Dardennes karst system exemplifies the hydrodynamic functioning of a highly dynamic karst aquifer. The lumped rainfall-discharge model is a useful tool to: i) validate the conceptual model of functioning of the aquifer and 2) give access to the hydrograph separation into slow flow and fast flow rates at each time- step. Situating the results with respect to the geological and speleogenetic context enables discussion 
on the flood assessment and the groundwater management. The lumped model was calibrated using the KarstMod platform, based on a quasi Monte-Carlo procedure with a Sobol sequence sampling of the parameter space. The best set of parameters was chosen over 10000 results that satisfy Wobj $>0.7$ (Wobj: aggregate objective function using the Nash-Sutcliffe Efficiency coefficient and balance error). The calibrated model correctly simulates the Dardennes springs' discharge, in low or high flow periods, with Wobj $=0.88$ in the validation period.

In such a dynamic aquifer, spring discharge varies quickly with rainfall recharge, generating a flood peak in one or two days. The quickflow is the main flow component during floods, accounting for up to more than $90 \%$ of the discharge. This hydrodynamic behavior is explained by the fast recharge to the well-connected and organized karst conduit network in the vadose and saturated zones of the aquifer. This study showed that a low rainfall intensity recharges the baseflow and a high Mediterranean rainfall recharges the slow and the fast components. A negative minimum water level and a threshold level were implemented in the first Epikarst reservoir of the model in order to simulate the storage or mitigation effect of rainfall below $30 \mathrm{~mm} / \mathrm{d}$ in the dry season. Above the threshold, the fast flow is activated and the recharge water height is transferred to the spring with a weak mitigation and dispersion, modelled with a high recession coefficient $\mathrm{k}_{\text {fast }}>1 \mathrm{~d}^{-1}$. On the contrary, the mean annual baseflow rate varied only slightly over the 3 years studied (normal, dry, wet years). The water level simulated in the conduit reservoir was also shown to be representative of the water level in the karst conduit network of the aquifer, observed in the Ragas cave and overflow spring. An estimate of the karst storage was calibrated, in the range $3 \times 10^{-4}$ to $6 \times 10^{-4}$.

The Dardennes geological study showed that there is a substantial groundwater reserve in depth, below the springs' outlet. Moreover the deep karstification below the springs allows the karst conduit network to connect and drain the matrix. The aquifer geometry and functioning are thus favorable for an active management by pumping groundwater from the conduit network below the springs. Decreasing the karst water level in summer will mitigate karst flash floods. Indeed, the simulated discharge in the case of a Mediterranean rain event showed that the karst will drastically increase the flood hazard in the stream downstream the springs that flow through Toulon.

The global approach to karst behavior could be improved by refining the time-step of the rainfall-discharge modeling. For highly dynamic karst, the daily time-step is adequate for global groundwater management but it minimizes the actual flood peak. If discharge or water level data are available, an hourly time-step could improve the karst flash-flood prediction.

The origin of the groundwater discharged was not studied, nor were the groundwater residence times. This would involve combining a hydrogeochemistry approach to deal with the mixing of different water origins. A further study will be to combine electrical conductivity time series with analyses of the major ions, stable water isotopes, $\mathrm{CFCs}$ and $\mathrm{SF}_{6}$. Nevertheless, the KarstMod tool has been developed to encourage and enhance the modeling of karst spring discharge time series, the comparison of case studies, and will open up new prospects on karst groundwater management.
Acknowledgements. The authors would like to thank the KARST observatory network (SNO KARST) initiative at the INSU/CNRS, which aims to strengthen knowledge-sharing and promote cross-disciplinary research on karst systems at the national scale, for providing the KarstMod platform. We also thank "Météo-France" for the meteorological data. We also thank the two reviewers who helped to clarify a previous version of the paper. This work is part of the DARDENNES project funded by the Agence de l'Eau (RMC), the city of Toulon, Veolia Eau, Cenote Company, and Aix-Marseille University. Results will be available on www.karsteau.fr. The KarstMod platform is free and available at www.sokarst.org.

\section{References}

Arfib B, Charlier JB. 2016. Insights into saline intrusion and freshwater resources in coastal karstic aquifers using a lumped Rainfall-Discharge-Salinity model (the Port-Miou brackish spring, SE France). Journal of Hydrology 540: 148-161. DOI: 10.1016/j. jhydrol.2016.06.010.

Arfib B, Novaes C, Baudement C, Dufresne C, Duffa C. 2016. Origin of flash flood water of a Mediterranean river in karstic and urban environments by CTD monitoring (Las - Toulon - SE France), Proceedings Eurokarst 2016, Neuchâtel.

Atkinson TC. 1977. Diffuse flow and conduit flow in limestone terrain in the Mendip Hills, Somerset (Great Britain). Journal of Hydrology 35(1): 93-110. DOI: 10.1016/0022-1694(77)90079-8.

Audra P, Mocochain L, Camus H, Gilli E, Clauzon G, Bigot JY. 2004. The effect of the Messinian Deep Stage on karst development around the Mediterranean sea. Examples from Southern France. Geodin Acta 17(6): 389-400. DOI: 10.3166/ga.17.389-400.

Audra, P, Palmer AN. 2013. 6.17 The vertical dimension of Karst: controls of vertical cave pattern. In: Shroder JF, ed. Treatise on Geomorphology, 6: 186-206. DOI: 10.1016/ b978-0-12-374739-6.00098-1.

Baedke SJ, Krothe NC. 2001. Derivation of effective hydraulic parameters of a karst aquifer from discharge hydrograph analysis. Water Resources Research 37(1): 13-19. DOI: 10.1029/ 2000wr900247.

Bakalowicz M. 1979. Contribution de la géochimie des eaux à la connaissance de l'aquifère karstique et de la karstification. $\mathrm{PhD}$ Thesis, Université Pierre et Marie Curie, $269 \mathrm{p}$.

Bakalowicz M. 2005. Karst groundwater: a challenge for new resources. Hydrogeology Journal 13 (1): 148-160. DOI: 10.1007/ s10040-004-0402-9.

Bestani L, Espurt N, Lamarche J, Floquet M, Philip J, Bellier O, et al. 2015. Structural style and evolution of the Pyrenean-Provence thrust belt, SE France. Bulletin de la Société géologique de France 186(4-5): 223-241. DOI: 10.2113/gssgfbull.186.4-5.223.

Beven K, Binley A. 1992. The future of distributed models: model calibration and uncertainty prediction. Hydrological Processes 6 (3): 279-298.

Bezès C. 1976. Contribution à la modélisation des systèmes aquifères karstiques; établissement du modèle Bemer; son application à quatre systèmes karstiques du midi de la France. $\mathrm{PhD}$ Thesis, Université des Sciences et Techniques du Languedoc, 135 p.

Blanc JJ. 1992. Importance geodynamique des surfaces d'aplanissement en Provence (analyse multicriteres). In : Salomon JN, Maire R, eds. Karst et évolutions climatiques; hommage à Jean Nicod. Talence : Presses Universitaires de Bordeaux, pp. 191-207.

Blanc JJ. 1997. Géodynamique et histoire du karst-Application au sud-est de la France [Paleokarsts, evolution and geodynamics. 
Application to the South-eastern France]. Quaternaire 8(2): 91105.

Butscher C, Huggenberger P. 2008. Intrinsic vulnerability assessment in karst areas: a numerical modeling approach. Water Resources Research 44(3): 15. DOI: 10.1029/2007wr006277.

Caine JS, Evans JP, Forster CB. 1996. Fault zone architecture and permeability structure. Geology 24(11): 1025-1028. DOI: 10.1130/ 0091-7613(1996)024<1025:Fzaaps >2.3.Co; 2 .

Chanat JG, Rice KC, Hornberger GM. 2002. Consistency of patterns in concentration-discharge plots. Water Resources Research 38(8): 22-1-22-10. DOI: 10.1029/2001wr000971.

Covington MD, Wicks CM, Saar MO. 2009. A dimensionless number describing the effects of recharge and geometry on discharge from simple karstic aquifers. Water Resources Research 45(11): 16. DOI: $10.1029 / 2009 w r 008004$.

Delbart C, Valdés D, Barbecot F, Tognelli A, Couchoux L. 2016. Spatial organization of the impulse response in a karst aquifer. Journal of Hydrology 537: 18-26. DOI: 10.1016/j.jhy drol.2016.03.029.

Denic-Jukic V, Jukic D. 2003. Composite transfer functions for karst aquifers. Journal of Hydrology 274(1): 80-94. DOI: 10.1016/ S0022-1694(02)00393-1.

Dubois C, Quinif Y, Baele JM, Barriquand L, Bini A, Bruxelles L, et al. 2014. The process of ghost-rock karstification and its role in the formation of cave systems. Earth-Science Reviews 131: 116148. DOI: 10.1016/j.earscirev.2014.01.006.

Fiorillo F. 2014. The recession of spring hydrographs, focused on Karst Aquifers. Water Resources Management 28(7): 1781-1805. DOI: $10.1007 / \mathrm{s} 11269-014-0597-z$.

Fleury P. 2005. Sources sous-marines et aquifères karstiques côtiers méditerranéens. Fonctionnement et caractérisation. $\mathrm{PhD}$ Thesis, Université Pierre et Marie Curie - Paris VI. tel-00789234, $286 \mathrm{pp}$.

Fleury P, Plagnes V, Bakalowicz M. 2007. Modelling of the functioning of karst aquifers with a reservoir model: application to Fontaine de Vaucluse (South of France). Journal of Hydrology 345 (1-2): 38-49. DOI: 10.1016/j.jhydrol.2007.07.014.

Fleury P, Ladouche B, Conroux Y, Jourde H, Dörfliger N. 2009. Modelling the hydrologic functions of a karst aquifer under active water management - The Lez spring. Journal of Hydrology 365(34): 235-243. DOI: 10.1016/j.jhydrol.2008.11.037.

Fleury P, Kong-A-Siou L, Johannet A, Darras T, Pistre S, Guilhalmenc M, et al. 2013. Rôle du Karst dans les crues du fleuve Lez. Karstologia 62: 41-48.

Ford D, Williams PD. 2013. Karst hydrogeology and geomorphology. Chichester: John Wiley \& Sons. DOI: 10.1002/9781118684986. ch5.

Fu TG, Chen HS, Wang KL. 2016. Structure and water storage capacity of a small karst aquifer based on stream discharge in southwest China. Journal of Hydrology 534: 50-62. DOI: 10.1016/ j.jhydrol.2015.12.042.

Gaume E, Bain V, Bernardara P, Newinger O, Barbuc M, Bateman A, et al. 2009. A compilation of data on European flash floods. Journal of Hydrology 367(1-2): 70-78. DOI: 10.1016/j.jhy drol.2008.12.028.

Geyer T, Birk S, Licha T, Liedl R, Sauter M. 2007. Multitracer test approach to characterize reactive transport in karst aquifers. Ground Water 45(1): 36-45. DOI: 10.1111/j.1745-6584.2006.00261.x.

Geyer T, Birk S, Liedl R, Sauter M. 2008. Quantification of temporal distribution of recharge in karst systems from spring hydrographs. Journal of Hydrology 348 (3-4): 452-463. DOI: 10.1016/j. jhydrol.2007.10.015.
Goldscheider N, Drew D. 2007. Methods in Karst hydrogeology: IAH: International Contributions to Hydrogeology, 26. Leiden (Netherlands): Taylor and Francis Group.

Guyonnet-Benaize C, Lamarche J, Masse JP, Villeneuve M, Viseur S. 2010. 3D structural modelling of small-deformations in poly-phase faults pattern. Application to the Mid-cretaceous durance uplift, provence (SE France). Journal of Geodynamics 50(2): 81-93. DOI: 10.1016/j.jog.2010.03.003.

Hartmann A, Lange J, Vivó Aguado À, Mizyed N, Smiatek G, Kunstmann H. 2012. A multi-model approach for improved simulations of future water availability at a large Eastern Mediterranean karst spring. Journal of Hydrology 468-469: 130-138. DOI: 10.1016/j.jhydrol.2012.08.024.

Häuselmann P, Jeannin PY, Bitterli T. 1999. Relationships between karst and tectonics: case-study of the cave system north of Lake Thun (Bern, Switzerland) Relations entre karst et tectonique: l'exemple du réseau spéléologique du nord du lac de Thoune (Berne, Suisse). Geodin Acta 12(6): 377-388. DOI: 10.1016/ s0985-3111(99)00104-7.

Hennuy J. 2003. Sédimentation carbonatée et silicoclastique sous contrôle tectonique, le Bassin Sud + Provençal et sa plate + forme carbonatée du Turonien moyen au Coniacien moyen : évolution séquentielle, diagénétique, paléogéographique. $\mathrm{PhD}$ Thesis, Université de Provence.

Herold T, Jordan P, Zwahlen F. 2000. The influence of tectonic structures on karst flow patterns in karstified limestones and aquitards in the Jura Mountains, Switzerland. Eclogae Geol Helv 93 (3): 349-362. DOI: 10.5169/seals-168827.

Hornberger GM, Spear RC. 1981. Approach to the preliminary analysis of environmental systems. J Environ Mgmt 12(1): 7-18.

Jourde H, Lafare A, Mazzilli N, Belaud G, Neppel L, Dörfliger N, et al. 2013. Flash flood mitigation as a positive consequence of anthropogenic forcing on the groundwater resource in a karst catchment. Environmental Earth Sciences 71(2): 573-583. DOI: 10.1007/s12665-013-2678-3.

Journey CA, Beaulieu KM, Bradley PM. 2013. Environmental factors that influence cyanobacteria and geosmin occurrence in reservoirs. Chapter 2, current perspectives in contaminant hydrology and water resources sustainability. DOI: $10.5772 / 54807$.

Jukić D, Denić-Jukić V. 2009. Groundwater balance estimation in karst by using a conceptual rainfall-runoff model. Journal of Hydrology 373 (3-4): 302-315. DOI:10.1016/j.jhy drol.2009.04.035.

Juttner F, Watson SB. 2007. Biochemical and ecological control of geosmin and 2-methylisoborneol in source waters. Applied and environmental microbiology 73(14): 4395-4406. DOI:10.1128/ AEM.02250-06.

Kovács A, Perrochet P. 2008. A quantitative approach to spring hydrograph decomposition. Journal of Hydrology 352(1-2): 1629. DOI:10.1016/j.jhydrol.2007.12.009.

Kovács A, Perrochet P, Király L, Jeannin P-Y. 2005. A quantitative method for the characterisation of karst aquifers based on spring hydrograph analysis. Journal of Hydrology 303 (1-4): 152-164. DOI:10.1016/j.jhydrol.2004.08.023.

Lacombe O, Jolivet L. 2005. Structural and kinematic relationships between Corsica and the Pyrenees-Provence domain at the time of the Pyrenean orogeny. Tectonics 24(1): 20. DOI:10.1029/ 2004 tc001673.

Ladouche B, Marechal J-C, Dorfliger N. 2014. Semi-distributed lumped model of a karst system under active management. Journal of Hydrology 509: 215-230. DOI:10.1016/j.jhy drol.2013.11.017. 
Lamarque T, Maurel P, Courbon P. 2008. Le Las : une rivière dans la ville. Synthèse sur l'environnement aquatique du Las et de la vallée de Dardennes. Toulon, Var, France. Association Val d'As. Val d'As: 264.

Laville P. 1981. La formation bauxitique provençale (France). Séquence des faciès chimiques et paléomorphologie Crétacé. Chronique de la recherche minière.

Leonide P, Fournier F, Reijmer JJG, Vonhof H, Borgomano J, Dijk J, et al. 2014. Diagenetic patterns and pore space distribution along a platform to outer-shelf transect (Urgonian limestone, Barremian-Aptian, SE France). Sedimentary Geology 306: 1-23. DOI:10.1016/j.sedgeo.2014.03.001.

Levens RL, Williams RE, Ralston DR. 1994. Hydrogeologic role of geologic structures. Part 1: the paradigm. Journal of Hydrology 156: 227-243.

Lucot JP, Chardin G. 2017. Fichier des cavités du Var (France). [Cave database of the Var region - France]. http://www.fichiertopo.fr/.

Mangin A. 1975. Contribution à l'étude hydrodynamique des aquifères karstiques. $\mathrm{PhD}$ Thesis, Laboratoire souterrain du Centre national de la recherche scientifique, Annales de Spéléologie, $49 \mathrm{p}$.

Maréchal JC, Ladouche B, Dörfliger N. 2008. Karst flash flooding in a Mediterranean karst, the example of Fontaine de Nîmes. Engineering Geology 99(3-4): 138-146. DOI:10.1016/j.eng geo.2007.11.013.

Masse JP, Philip J. 1976. Paléogéographie et tectonique du Crétacémoyen en Provence: révision du concept d'isthme durancien. Revue de Géographie Physique et de Géologie Dynamique 18(1): 49-66.

Mathevet T, Lepiller M, Mangin A. 2004. Application of time-series analyses to the hydrological functioning of an Alpine karstic system: the case of Bange-L'Eau-Morte. Hydrol Earth Syst Sc 8(6): 1051-1064.

Matonti C. 2015. Exploration géophysique des processus de fracturation et de réactivation dans les carbonates à l'échelle métrique. PhD Thesis, Aix-Marseille University, $170 \mathrm{p}$.

Matonti C, Lamarche J, Guglielmi Y, Marie L. 2012. Structural and petrophysical characterization of mixed conduit/seal fault zones in carbonates: example from the Castellas fault (SE France). Journal of Structural Geology 39: 103-121. DOI:10.1016/j. jsg.2012.03.003.

Mazzilli N, Guinot V, Jourde H. 2012. Sensitivity analysis of conceptual model calibration to initialisation bias. Application to karst spring discharge models. Advances in Water Resources 42: 1-16. DOI:10.1016/j.advwatres.2012.03.020.

Mazzilli N, Guinot V, Jourde H, Lecoq N, Labat D, Arfib B, et al. 2017. KarstMod: a modelling platform for rainfall-discharge analysis and modelling dedicated to karst systems. Environmental Modelling and Software (in press): 7.

Mazzilli N, Jourde H, Guinot V, Bailly-Comte V, Fleury P. 2011. Hydrological modelling of a karst aquifer under active groundwater management using a parsimonious conceptual model, H2Karst Conference (1-3 septembre 2011), Besançon, France.

Mero F. 1964. Barbutium springs follow up report (September 1963 to May 1964).

Merz R, Bloschl G. 2003. A process typology of regional floods. Water Resources Research 39(12): 20 p. DOI:10.1029/ 2002 wr001952.

Meteo-France. 2017a. Database of rainfall exceptional events in the area of Toulon - Dardennes study site (Var "Département") : http:// pluiesextremes.meteo.fr/france-metropole/Var.html.
Meteo-France, 2017b. Exceptional rainfal event of Draguignan 15th June 2010: http://pluiesextremes.meteo.fr/france-metropole/ Catastrophe-de-Draguignan.html.

Miller JD, Kim H, Kjeldsen TR, Packman J, Grebby S, Dearden R. 2014. Assessing the impact of urbanization on storm runoff in a peri-urban catchment using historical change in impervious cover. Journal of Hydrology 515: 59-70. DOI:10.1016/j.jhy drol.2014.04.011.

Mocochain L, Audra P, Bigot JY. 2011. Base level rise and per ascensum model of speleogenesis (PAMS). Interpretation of deep phreatic karsts, vauclusian springs and chimney-shafts. Bulletin de la Société géologique de France 182(2): 87-93. DOI:10.2113/ gssgfbull.182.2.87.

Mocochain L, Audra P, Clauzon G, Bellier O, Bigot J- Y, Parize O, et al. 2009. The effect of river dynamics induced by the Messinian Salinity Crisis on karst landscape and caves: example of the Lower Ardèche river (mid Rhône valley). Geomorphology 106(1-2): 4661. DOI: 10.1016/j.geomorph.2008.09.021.

Nash JE, Sutcliffe JV. 1970. River flow forecasting through conceptual models part I-a discussion of principles. Journal of Hydrology 10(3): 282-290.

Nied M, Pardowitz T, Nissen K, Ulbrich U, Hundecha Y, Merz B. 2014. On the relationship between hydro-meteorological patterns and flood types. Journal of Hydrology 519: 3249-3262. DOI:10.1016/j.jhydrol.2014.09.089.

Padilla-Benitez A. 1990. Los modelos matématicos aplicados al analisis de los acuiferos karsticos. PhD Thesis, $267 \mathrm{p}$.

Padilla A, Pulido- Bosch A. 1995. Study of hydrographs of karstic aquifers by means of correlation and cross-spectral analysis. Journal of Hydrology 168(1-4): 73-89.

Padilla A, Pulido- Bosch A, Mangin A. 1994. Relative importance of baseflow and quickflow from hydrographs of Karst spring. Ground Water 32(2): 267-277. DOI: 10.1111/j.1745-6584.1994.tb00641.x.

Perrin J, Jeannin PY, Cornaton F. 2007. The role of tributary mixing in chemical variations at a karst spring, Milandre, Switzerland. Journal of Hydrology 332(1-2): 158-173. DOI:10.1016/j.jhydrol.2006.06.027.

Rimmer A, Hartmann A. 2012. Simplified conceptual structures and analytical solutions for groundwater discharge using reservoir equations. In: InTechOpen, ed. Water Resources Management and Modeling, p. 23.

Roesch A, Jourde H. 2006. Incidence d'une gestion active de la ressource en eau en milieu karstique sur le risque hydrologique. Exemple du fleuve Lez (Montpellier, France), GIRE3D Conférence, Marrakech.

Roure F, Brun JP, Colletta B, Vandendriessche J. 1992. Geometry and kinematics of extensional structures in the alpine foreland basin of southeastern france. Journal of Structural Geology 14(5): 503-519. DOI:10.1016/0191-8141(92)90153-N.

Roure F, Colletta B. 1996. Cenozoic inversion structures in the foreland of the Pyrenees and Alps. Mémoires du Muséum national d'histoire naturelle 170: 173-209.

Ruin I, Lutoff C, Boudevillain B, Creutin J-D, Anquetin S, Rojo MB, et al. 2014. Social and Hydrological responses to extreme precipitations: an interdisciplinary strategy for postflood investigation. Weather, Climate, and Society 6(1): 135-153. DOI:10.1175/ wcas-d-13-00009.1.

Saltelli A. 2002. Making best use of model evaluations to compute sensitivity indices. Comput Phys Commun 145(2): 280-297. DOI:10.1016/S0010-4655(02)00280-1.

Saltelli A, Ratto M, Andres T, Campolongo F, Cariboni J, Gatelli D, et al. 2008. Global sensitivity analysis: the primer. New York: John Wiley \& Sons. 
Valdes D, Dupont J-P, Massei N, Laignel BT, Rodet J. 2006. Investigation of karst hydrodynamics and organization using autocorrelations and T- $\Delta$ C curves. Journal of Hydrology 329(3-4): 432-443. DOI:10.1016/j.jhydrol.2006.02.030.

Vannier O, Anquetin S, Braud I. 2016. Investigating the role of geology in the hydrological response of Mediterranean catchments prone to flash-floods: Regional modelling study and process understanding. Journal of Hydrology 541: 158-172. DOI:10.1016/ j.jhydrol.2016.04.001.

White WB. 2007. A brief history of karst hydrogeology: contributions of the NSS. Journal of Cave and Karst Studies 69(1): 13-26.

Cite this article as: Baudement C, Arfib B, Mazzilli N, Jouves J, Lamarque T, Guglielmi Y. 2017. Groundwater management of a highly dynamic karst by assessing baseflow and quickflow with a rainfall-discharge model (Dardennes springs, SE France), Bull. Soc. géol. Fr. 188: 40 . 